THALLES RICARDO ALCIATI VALIM

Análise tipológica do contrato de doação

\author{
Dissertação de Mestrado
}

Orientador: Professor Associado Dr. Otavio Luiz Rodrigues Junior

UNIVERSIDADE DE SÃO PAULO

FACULDADE DE DIREITO

São Paulo - SP

2019 

THALLES RICARDO ALCIATI VALIM

\section{Análise tipológica do contrato de doação}

Dissertação apresentada à Banca Examinadora do Programa de Pós-Graduação em Direito, da Faculdade de Direito da Universidade de São Paulo, como exigência parcial para a obtenção do título de Mestre em Direito, na área de concentração de Direito Civil, sob a orientação do Professor Associado Dr. Otavio Luiz Rodrigues Junior.

UNIVERSIDADE DE SÃO PAULO

FACULDADE DE DIREITO

São Paulo - SP

2019 
V172a Valim, Thalles Ricardo Alciati

Análise tipológica do contrato de doação / Thalles Ricardo Alciati Valim. - São Paulo: Faculdade de Direito - Universidade de São Paulo, 2019. $357 \mathrm{p}$.

Dissertação (Direito Civil) - Faculdade de Direito - Universidade de São Paulo: São Paulo, 2019 .

Orientador: Dr. Otavio Luiz Rodrigues Junior

1. Tipicidade contratual. 2. Doação. 3. Liberalidades atípicas. 4. Contratos mistos. 5. Interpretação contratual. I. Título.

CDU 347.440 .2 
Banca Examinadora: 

Thalles Ricardo Alciati Valim. Análise tipológica do contrato de doação. 2019. 357 p. Mestrado em Direito - Faculdade de Direito, Universidade de São Paulo, 2019.

\section{RESUMO}

Este estudo tem por objetivo desenvolver um método de construção do regime jurídico aplicável aos contratos típicos (legais e sociais) e atípicos (mistos e puros) para utilizá-lo na análise da qualificação do contrato de doação e das liberalidades atípicas. Para isso, investigam-se: (i) as diferenças entre os métodos conceitual-subsuntivo e tipológicoanalógico; (ii) os critérios de identificação dos contratos mistos; (iii) os processos de interpretação e qualificação dos contratos; (iv) os índices do tipo da doação; e (v) a qualificação e o regime jurídico do negotium mixtum cum donatione, da estipulação em favor de terceiro causa donandi, do pagamento de dívida alheia causa donandi e das dádivas.

Palavras-chave: Tipicidade contratual. Doação. Liberalidades atípicas. Contratos mistos. Interpretação contratual. 

Thalles Ricardo Alciati Valim. Typological analysis of the gift. 2019. 357 p. Master's Degree - Faculty of Law, University of São Paulo, 2019.

\begin{abstract}
This study aims to develop a method to identify the applicable rules regarding social and legal contractual types, as well as the atypical contracts, in order to be applied to the analysis of donation and other gifts' legal classification. To do so, we investigate the: (i) differences between the conceptual and the typological methods; (ii) criteria for identifying mixed contracts; (iii) procedures for contractual interpretation and classification; (iv) elements of the donation type; and (v) classification and the legal regime of negotium mixtum cum donatione, contracts for the benefit of third parties, performance of an obligation by a third party and costumary gifts.
\end{abstract}

Keywords: Types of contract. Donation. Gifts. Mixed contracts. Interpretation of contracts. 

Thalles Ricardo Alciati Valim. Analyse typologique du contrat de donation. 2019. 357 p. Master en Droit - Faculté de Droit, Université de São Paulo, 2019.

\section{RÉSUMÉ}

Cette étude a pour objet le développement d'une méthode permettant d'identifier le règles juridiques applicables aux contrats nommés, ainsi que aux contrats innomés. Pour ce faire, nous cherchons: (i) les différences entre les méthodes conceptuelle et typologique; (ii) les critères pour l'identification des contrats mixtes; (iii) les procédures d'interprétation et de qualification des contrats; (iv) les indices du type contractuel de la donation; et (v) la qualification et le régime juridique de la donation mixte, de la stipulation pour autrui, du paiement par un tiers et des présents d'usage.

Mots-clés: Types de contrats. Donation. Donations indirectes. Contrats mixtes. Interprétation des contrats. 



\section{AGRADECIMENTOS}

Foram diversos os doadores, no sentido amplo do termo, que contribuíram para que essa pesquisa fosse realizada. É chegada a hora de cumprir a obrigação moral de retribuir essas liberalidades, com a nossa gratidão.

À Fundação de Amparo à Pesquisa do Estado de São Paulo (FAPESP), por ter financiado nossa pesquisa (Processo n. 17/06062-9), garantindo as condições econômicas essenciais para a dedicação integral à investigação do tema aqui analisado.

Ao Professor Associado Otavio Luiz Rodrigues Junior, nosso orientador em todos os aspectos da vida, mestre que nos abriu as portas para o Mestrado e nos concedeu uma janela sobre a qual pudemos olhar privilegiadamente para o Direito Civil contemporâneo.

Ao Professor Associado José Fernando Simão, pelas primeiras lições de Direito Civil, pela primeira orientação em pesquisa acadêmica, ainda na Graduação, e pelas sugestões, sempre bem-vindas, na banca de qualificação.

Ao Professor Associado Claudio Luiz Bueno de Godoy, pelos conselhos dados na banca de qualificação.

A todos os professores que nos formaram a pessoa que somos hoje. Especialmente, à Professora Terezinha, que nos ensinou a gostar de matemática na Terceira Série, e à Professora Valéria, que fez de cada aula de História uma viagem.

À nossa mãe, Carla Coracy de Carvalho Alciati, por ter nos dado à luz e continuar mantendo-a acesa com seus permanentes incentivo e confiança.

Às nossas irmãs, Lerys Alciati Valim e Laís Alciati Henriques, por nos lembrarem que não estamos sós.

Aos nossos avós, Maria Eugênia de Carvalho Alciati e Valdir Alaor Alciati, pelas melhores férias de verão que uma criança poderia ter e, acima de tudo, pelo amor irrestrito.

Ao nossos tios e, em especial, a Valdir Alaor Alciati Junior, por ter acreditado em nós e nos incentivado, moral e financeiramente. Essa e outras conquistas foram obtidas, sem dúvida, graças a ele. 
Ao Felipe Angel Bocchi Castellaro, pelo amor, companheirismo e incentivo. Em especial, pela revisão cuidadosa de todo o texto dessa pesquisa e pela paciência em nos ensinar a formatá-lo.

Aos nossos amigos, Marilia Troyano de Castro Mendes, Alex Dalmazzo Salto, Thais Juliana Ribeiro da Silva, Talita Salgado da Rocha, João Pedro Biazi, João Albano e Jorge Pedroso, pela dádiva da amizade.

Ao Mauricio Baptistella Bunazar, por nosso primeiro emprego no mundo jurídico, por ter se tornado nosso amigo e, por isso, mais do que tudo, nosso agradecimento.

Ao Fernando Speck de Souza, colega de Mestrado que se tornou grande amigo, pelo auxílio com a coleta de algumas das obras consultadas e pela leitura do texto dessa pesquisa.

A todos os funcionários da Faculdade de Direito do Largo de São Francisco, pelo apoio essencial. Em especial, à bibliotecária Maria dos Remédios, que tanto nos ajudou com a observância das normas técnicas da ABNT.

Ao Professor Luciano de Camargo Penteado, in memoriam, dedicamos essa pesquisa. Conhecemo-lo através de seus escritos e lamentamos sua passagem precoce. Esse estudo foi instigado pelos seus ensinamentos. 


\section{SUMÁRIO}

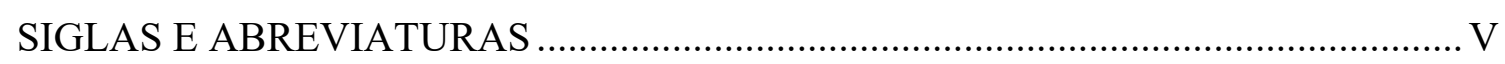

INTRODUÇÃ

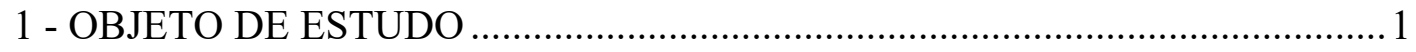

2 - MÉTODO DA PESQUISA …......................................................................... 4

3 - FORMATO DAS CITAÇÕES DOUTRINÁRIAS ............................................ 6

4 - USO DE FONTES JURISPRUDENCIAIS ................................................... 7

TÍTULO I. TIPICIDADE CONTRATUAL .....................................................................9

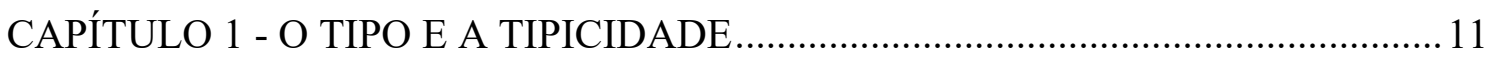

Seção I - Noções de tipo e de tipicidade ...................................................................... 11

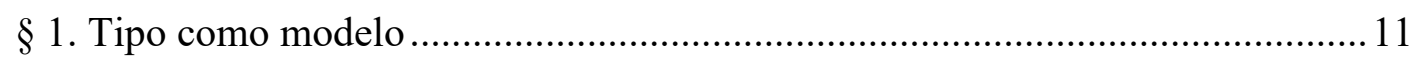

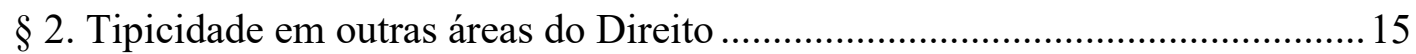

§ 3. Contratos típicos e contratos nominados …..................................................... 16

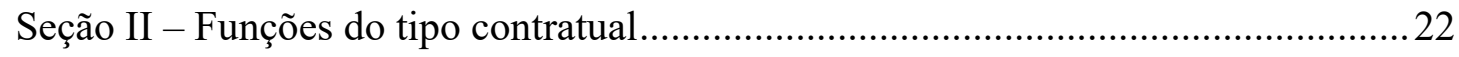

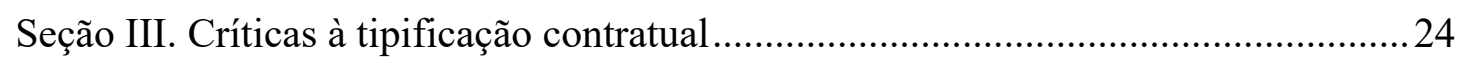

$\S 1$. Abandono do tipo em favor das classes contratuais ......................................25

$\S 2$. Abandono do tipo em favor da "análise do caso concreto" mediante a

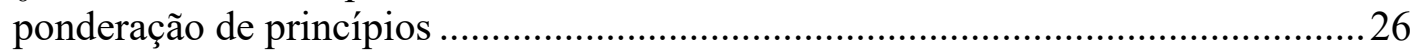

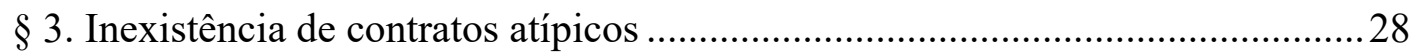

$\S$ 4. Reformulação da tipificação contratual sob a perspectiva da "Análise Econômica do Direito" (Law and Economics) .......................................................2 29

Seção IV - Método conceitual-subsuntivo e método tipológico-analógico................... 33

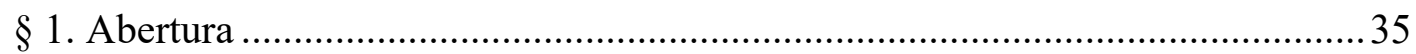

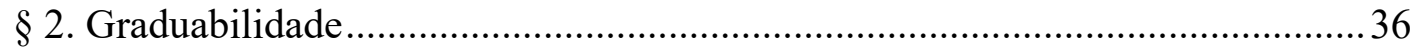

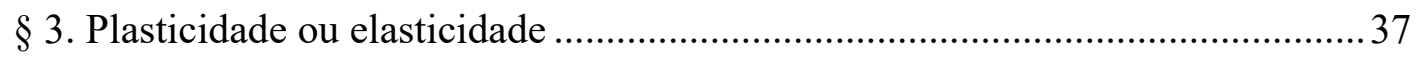

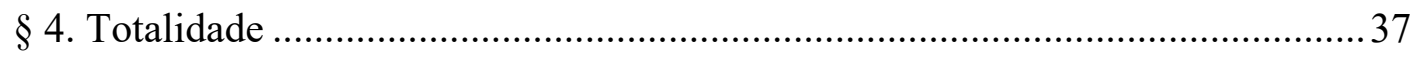

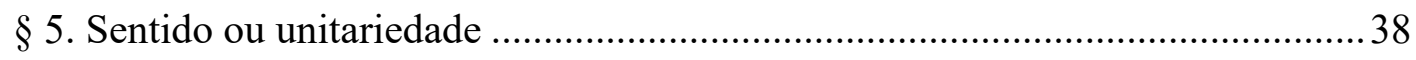

CAPÍTULO 2 - VARIANTES DE TIPICIDADE E ATIPICIDADE ............................. 41

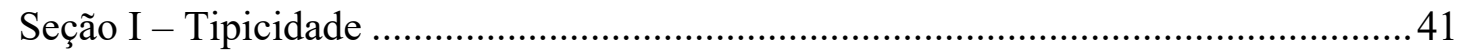

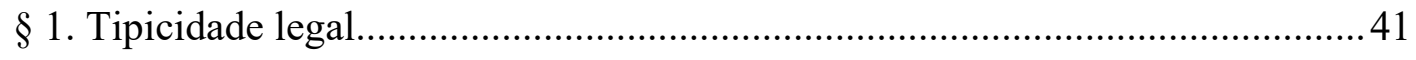

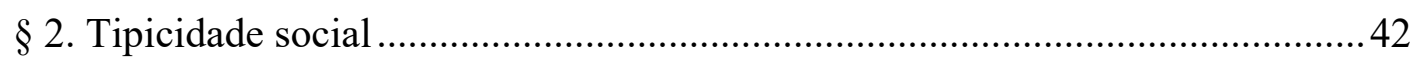

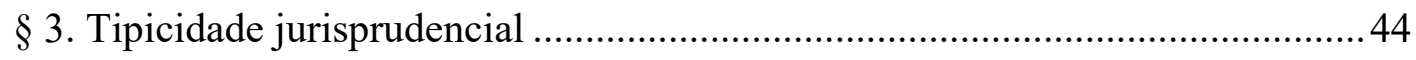

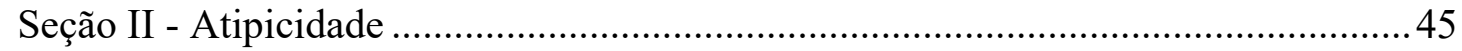

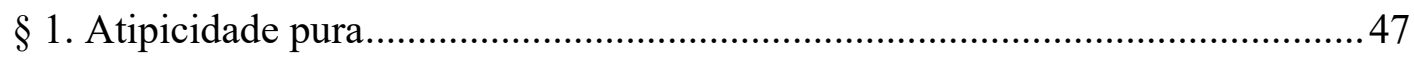

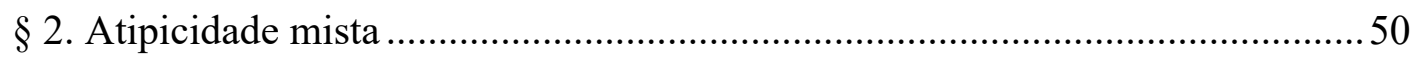

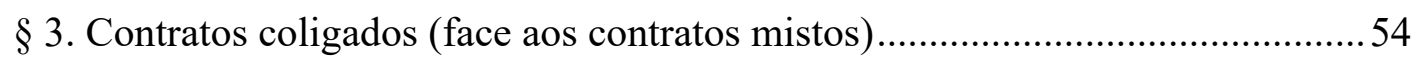

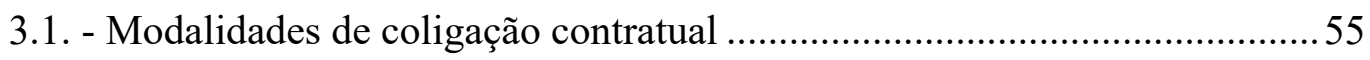


3.1.1. Classificação de ENNECCERUS/LEHMANN .....................................55

3.1.2. Classificação de PONTES DE MIRANDA ............................................55

3.1.3. Classificação de F. PAULO DE CRESCENZO MARINO ....................56

3.1.4. Classificação de RODRIGO XAVIER LEONARDO ............................58

3.2. - Critérios de identificação de contratos conexos ..........................................63

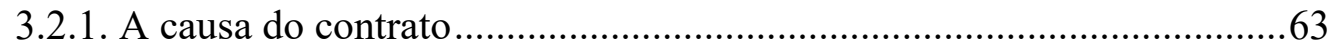

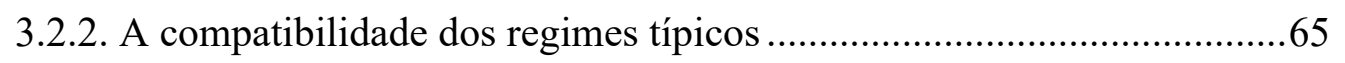

3.2.3. A contemporaneidade dos contratos ...................................................67

3.2.4. A pluralidade de instrumentos negociais ............................................67

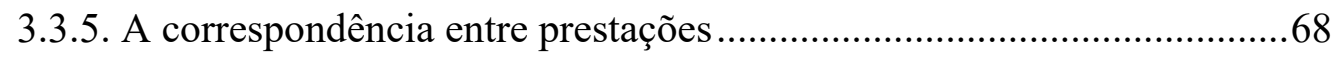

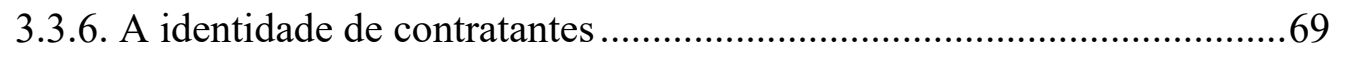

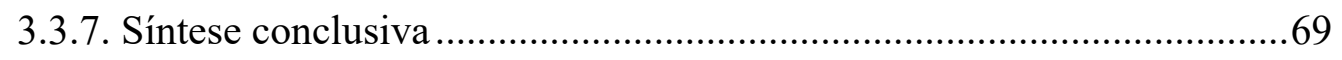

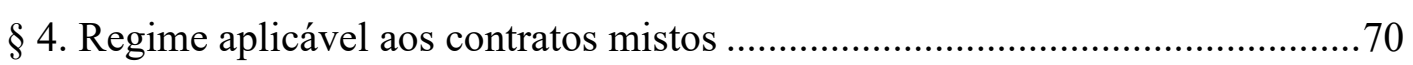

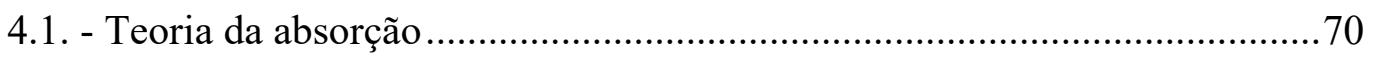

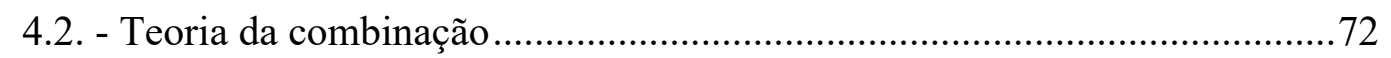

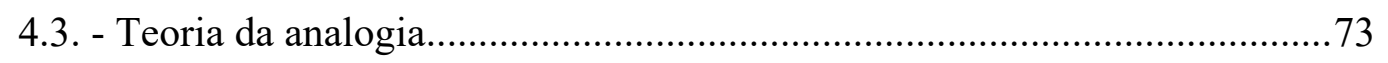

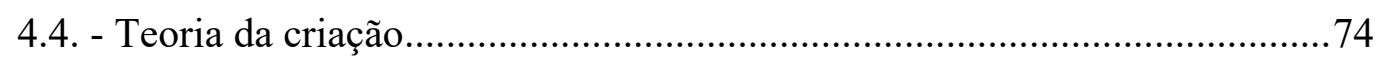

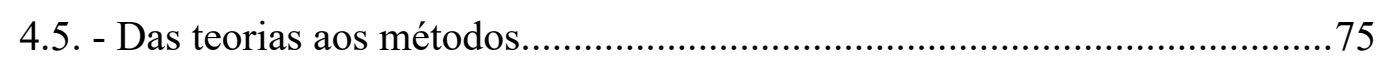

4.5.1. Escolha do método a partir do objeto da norma.....................................76

4.5.2. Escolha do método a partir da espécie de contrato misto ......................77

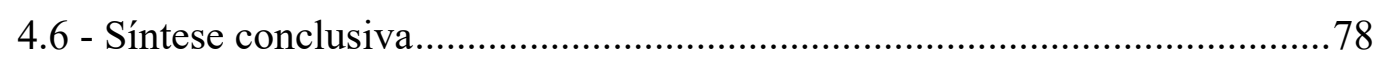

CAPÍTULO 3 - INTERPRETAÇÃO E QUALIFICAÇÃO CONTRATUAIS ................81

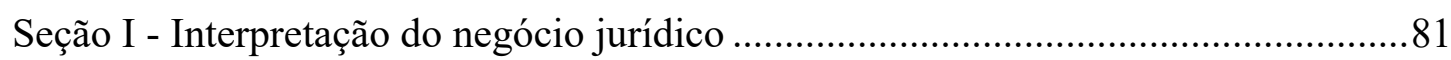

§ 1. Interpretação subjetiva e interpretação objetiva................................................. 81

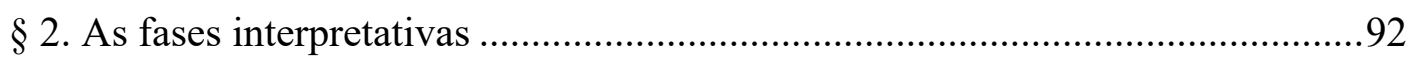

2.1 - Fase meramente recognitiva ............................................................. 92

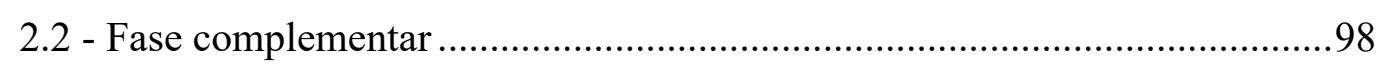

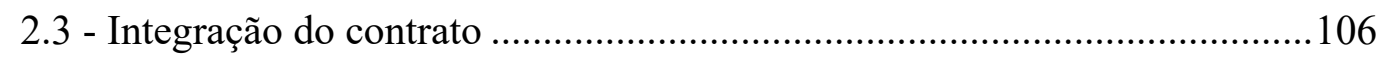

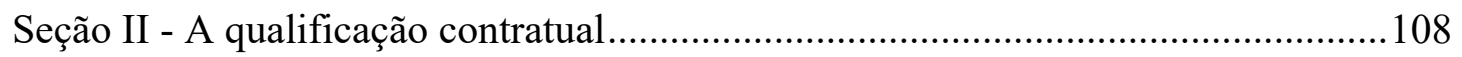

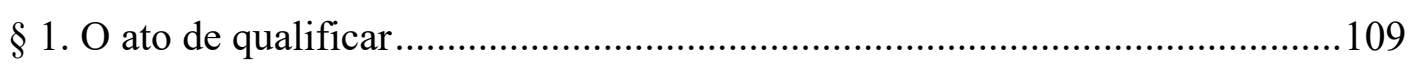

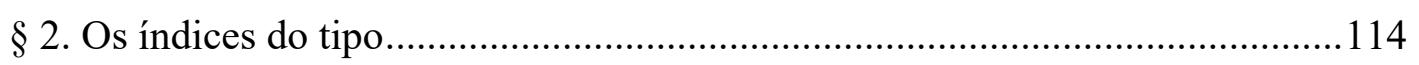

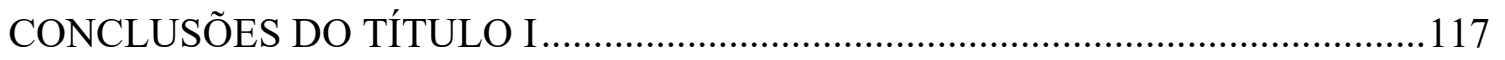

TÍTULO II. QUALIFICAÇÃO DO CONTRATO DE DOAÇÃO................................123

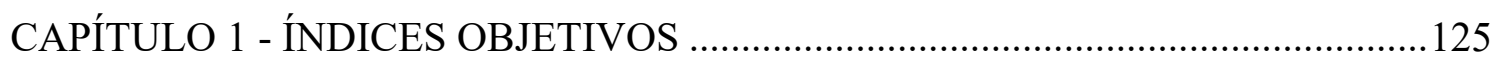

Seção I - O conteúdo do contrato e a gratuidade da doação .......................................125

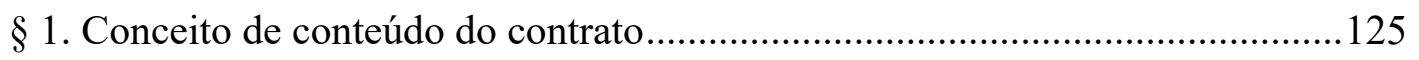

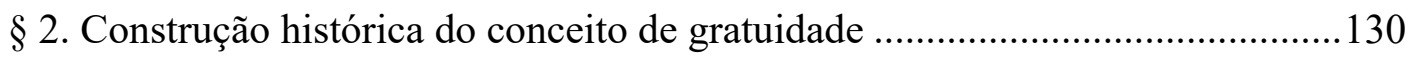

§ 3. A gratuidade como ausência de contraprestação ............................................137 
3.1. - Contraprestação como equivalente econômico (critério objetivo) 141

3.2. - Contraprestação como interesse racional .............................................. 142

3.3. - Contraprestação como equivalente subjetivo (critério subjetivo) ............ 145

3.4. - Contraprestação como estrutura típica ................................................... 149

3.5. - Contraprestação como onerosidade excessiva........................................... 149

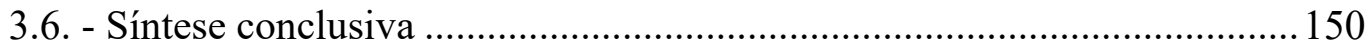

Seção II - O objeto do contrato e a transferência patrimonial .................................... 153

$\S 1$. Construção histórica do conceito de objeto do contrato .................................. 153

§ 2. O objeto do contrato de doação ................................................................ 167

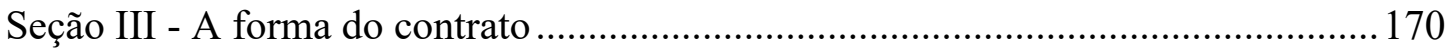

Seção IV - Fatores temporais e a definitividade da transferência patrimonial ........... 181

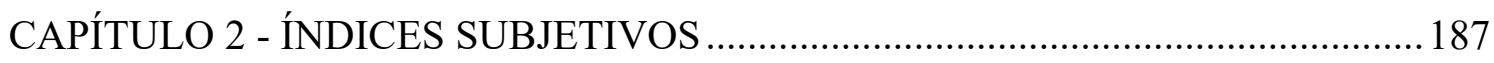

Seção I - A qualidade das partes e a revogação por ingratidão ................................. 187

Seção II - A qualificação voluntária ........................................................................ 194

Seção III - O fim contratual e o animus donandi ....................................................... 196

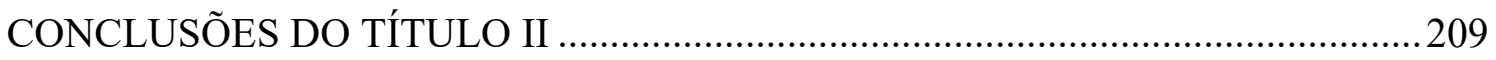

TÍTULO III. TIPOLOGIA DAS LIBERALIDADES ATÍPICAS.............................. 215

CAPÍTULO 1 - NEGOTIUM MIXTUM CUM DONATIONE ........................................22

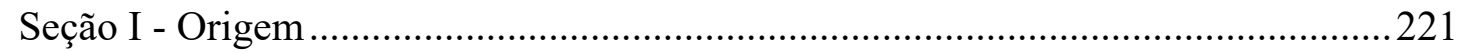

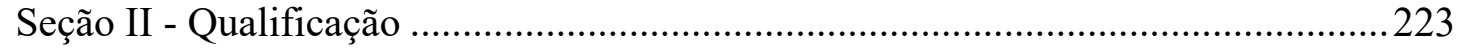

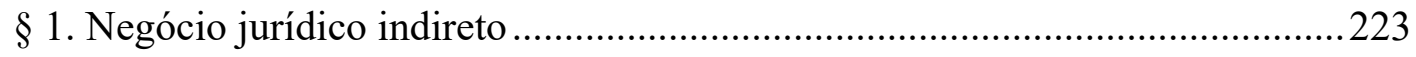

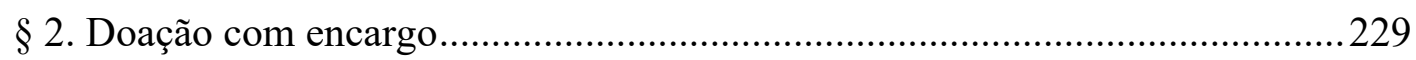

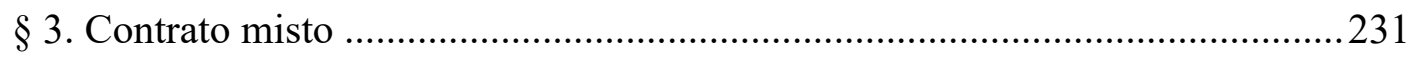

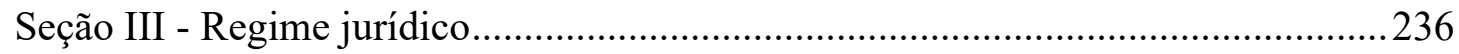

$\S 1$. Incidência das regras aplicáveis aos contratos onerosos ..............................239

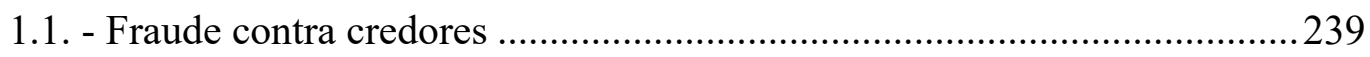

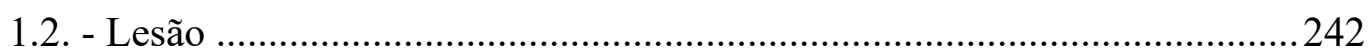

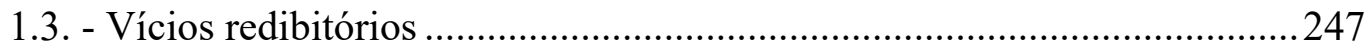

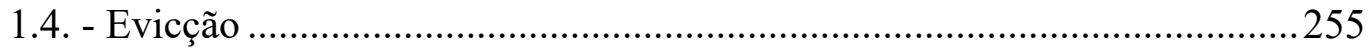

$\S 2$. Incidência das regras aplicáveis aos contratos gratuitos............................... 258

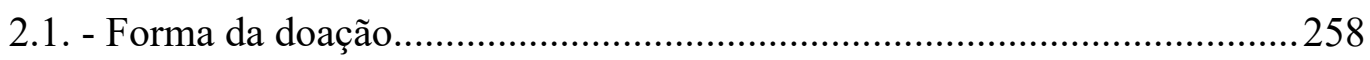

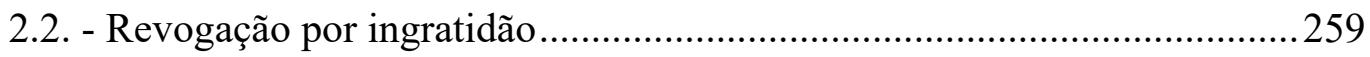

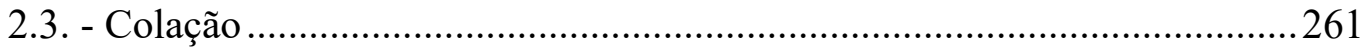

CAPÍTULO 2 - OUTRAS LIBERALIDADES ATÍPICAS ..........................................269

Seção I - Estipulação em favor de terceiro ..............................................................269

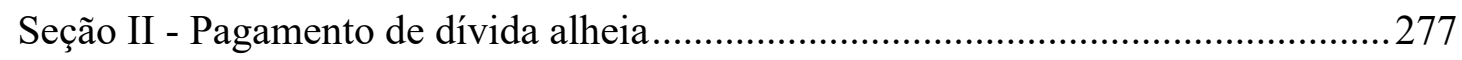

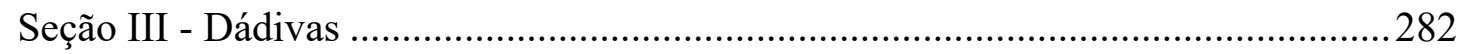

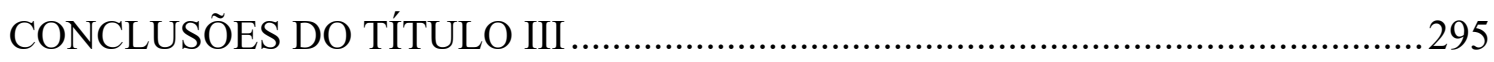




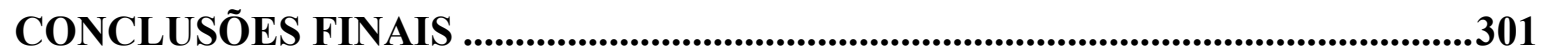

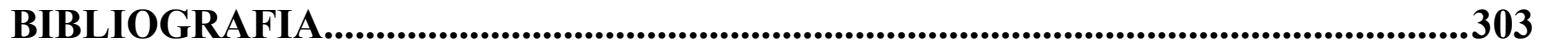




\section{SIGLAS E ABREVIATURAS}

ABNT - Associação Brasileira de Normas Técnicas

Ampl. - Ampliada

ANATEL — Agência Nacional de Telecomunicações

Art. - Artigo

Ass. plén. - Corte de Cassação francesa (Assemblée plénière)

Atual. - Atualizada

BGB — Código Civil alemão (Bürgerliches Gesetzbuch)

Bull.civ., ass.plén. - Boletim de julgados da Corte de Cassação francesa (Assemblée plénière)

Bull.civ., ch.mixte - Boletim de julgados da Corte de Cassação francesa (chambre mixte)

Bull.civ. I, II, III, IV ou V - Boletim de julgados da Corte de Cassação francesa (respectivamente, 1 ère , 2 ème e 3 ème câmaras civis; câmara comercial e câmara social)

Cap. - Capítulo

CCB — Código Civil brasileiro (Lei n $\left.{ }^{\circ} 10.406 / 2002\right)$

CCE — Código Civil espanhol (Real Decreto de 24 de julho de 1889)

CCF — Código Civil francês

CCIt — Código Civil italiano (Regio Decreto 16 marzo 1942, n. 262)

CCP — Código Civil português (Decreto-Lei n. 47344/66, de 25 de Novembro)

CDC — Código de Defesa do Consumidor (Lei n. 8.078/1990)

Cf. - Conferir

Civ.1 ère , Civ.2 ème , Civ. 3 ème - Câmaras civis da Corte de Cassação francesa 
Com. - Câmara Comercial da Corte de Cassação francesa

CCyCA — Código Civil e Comercial da Nação Argentina (Lei n. 26.994 de 7 de outubro de 2014)

D. - Digesto ou Pandectas do Imperador Justiniano

Ed. - Edição

Fasc. - Fascículo

Gai. - Institutas de Gaio

Gl. - Glosa

LGDJ — Librairie Générale de Droit et Jurisprudence (editora)

LINDB — Lei de Introdução às normas do Direito brasileiro (Decreto-Lei n. 4.657/1942)

N. - Número

Ord. Af. — Ordenações Afonsinas (1446 d.C.)

Ord. Fil. — Ordenações Filipinas (1595/1603 d.C.)

Ord. Man. - Ordenações Manuelinas (1513 d.C.)

PDEC - Princípios de Direito Europeu dos Contratos (Principles of European Contract Law - Comissão Öle Lando)

PUF — Presses Universitaires de France (editora)

Rev. - Revista

S.E.C. - Sem editor conhecido

STJ — Superior Tribunal de Justiça

T. - Tomo

Tít. - Título

UNIDROIT — Instituto Internacional para a Unificação do Direito Privado 
V. - Volume 


\title{
INTRODUCÃO
}

\section{1 - OBJETO DE ESTUDO}

\author{
Miseros cidadãos, que tanta insania! \\ De volta os Gregos ou de engano exemptos \\ Seus dons julgais? desconheceis Ulysses? \\ Ou este lenho he couto de inimigos, \\ Ou machina que, armada contra os muros, \\ Vem cimeira espiar e acommetter-nos? \\ Teucros, seja o que for, ha damno occulto, \\ Não fieis do cavallo: eu temo os Danaos, \\ Mesmo em seus brindes ${ }^{1}$.
}

A lenda do Cavalo de Troia bem representa a aura de suspeição que rodeia as liberalidades. As advertências de Laocconte não foram suficientes para evitar a ruína da cidade teucra. Se, para a compra e venda, o lema é caveat emptor, na doação, algo equivalente poderia ser dito, mas para ambas as partes. De um lado, teme-se que o doador vá dispor de seus bens de modo irrefletido e precipitado. De outro, que o donatário não perceba que, por detrás do ato de liberalidade, algum ônus se esconde sob as vestes de um encargo ou, até mesmo, de obrigações que surgirão no futuro.

Inicialmente relegada à causa de atribuição patrimonial, a doação passou para o campo dos contratos sob vestes formais. Esse foi o preço de seu reconhecimento jurídico. O recorte da realidade feito pelo Direito deixou, contudo, de fora da doação diversas liberalidades que não alcançavam a mesma estrutura: presentes módicos dados em ocasiões festivas, atos de generosidade ao se pagar a dívida de um amigo ou parente próximo, negócios onerosos em que uma certa desproporção entre as vantagens e benefícios era conscientemente planejada para beneficiar gratuitamente uma das partes. Todas essas figuras escapavam dos moldes conferidos à doação pelo Direito.

\footnotetext{
1 "O miseri, quae tanta insania, ciues? / Creditis auectos hostis? aut ulla putatis / Dona carere dolis Danaum ? sic notus Vlixes? / Aut hoc inclusi ligno occultantur Achiui, / aut haec in nostros fabricata est machina muros, / inspectura domos uenturaque desuper urbi, / aut aliquis latet error ; equo ne credite, Teucri. I Quidquid id est, timeo Danaos et dona ferentes". Versão em latim e tradução de: VIRGILIO. Eneida. In: MENDES, Manuel Odorico. Virgilio Brazileiro. Paris: W. Remquet e Cia., 1858, p. 254-255.
} 
A palavra molde é bem representativa desse fenômeno. Os contratos, ao serem reconhecidos pelo ordenamento, ganham um modelo normativo e são, assim, tipificados. A palavra tipo, tem origem no latim typus, que significa precisamente modelo, característica, representação. Tipo também é termo associado aos moldes utilizados na imprensa. De certa forma, a tipificação contratual é uma impressão da realidade feita pela superestrutura do Direito. Essa impressão implica um negativo, tudo aquilo que não está ali contido é atípico.

Se a tipificação permite identificar com relativa facilidade os regimes jurídicos dos contratos típicos, o que dizer dos atípicos? Para isso, a doutrina apresenta diversos critérios e classificações, tentando estabelecer mecanismos de construção do regime jurídico dos contratos atípicos.

No âmbito do direito dos contratos, há uma tensão permanente entre os contratos típicos - isto é, aqueles que contam com disciplina legal - e contratos atípicos, fruto da criatividade do mercado e dos agentes particulares. A presente pesquisa insere-se nesse contexto, buscando obter resposta, mediante o método dialético de pesquisa bibliográfica, a três perguntas: (i) é possível a incidência de parte do regime de um contrato típico em um contrato atípico? (ii) quais as regras do regime típico devem incidir num contrato atípico? (iii) quais os critérios que determinam essa incidência?

Esta pesquisa busca a aplicação dos resultados dessas três indagações para a hipótese do regime típico da doação em face de contratos atípicos que possuam parcialmente algum intuito gratuito. Ou seja, a depender dos resultados obtidos, poderemos verificar a solução adequada para contratos que não apresentam a estrutura típica de doação, mas que, no entanto, dela se aproximam. A questão da regulação dos mais diversos contratos a que a realidade social dá origem é um problema que, em certa medida, remete ao método tipológico adotado pelo sistema do direito contemporâneo.

Quando se tem em mente que o ordenamento jurídico apresenta um conjunto distinto de princípios e regras para as categorias dos contratos onerosos contrastadas à dos gratuitos, a questão de se saber em que medida as regras restritivas às liberalidades incidem também nos contratos atípicos é posta em evidência. Com isto, as questões subsequentes que a pesquisa tenta responder transportando os resultados das perguntas acima elecandas para o contrato de doação são: (i) no que diferem as doações com encargo dos negócios indiretos que porventura tenham intenção liberal neles embutida, assim como dos negócios mistos que igualmente apresentem, em alguma medida, uma liberalidade? (ii) como o regime típico 
disposto para as doações participa no processo de interpretação e integração do regulamento contratual desses negócios?

Pode-se dizer, portanto, que esse estudo possui um duplo objeto de estudo. De um lado, estudamos a tipicidade contratual e o método tipológico-analógico como mecanismos de construção dos regimes jurídicos incidentes nos contratos. De outro, analisamos como esse método pode ser aplicado às doações típicas e às liberalidades atípicas.

Pretende-se, com isso, apresentar conclusões com aportes práticos não só para o campo das liberalidades, mas também para a Teoria Geral dos Contratos. O método tipológico-analógico aqui descrito e defendido pode ser aplicado, em tese, a qualquer outro fenômeno contratual, embora seja mais adequado para hipóteses que conflitem com conceitos fechados como o de certos contratos típicos. É o caso das liberalidades atípicas em face das doações.

Assim, o presente estudo é divido em dois grandes eixos. Num primeiro momento, voltamos nossas atenções para o papel do método tipológico na construção do regime contratual. Isto é, tendo em vista a disposição de regimes contratuais legais típicos, qual seria a sua função na conformação concreta das normas reguladoras de cada contrato, bem como na composição dos regimes contratuais atípicos. Com as conclusões obtidas nessa primeira etapa, passamos à análise da interpretação e integração contratuais. Dito de outro modo, estudamos o processo de identificação do conteúdo contratual e seus elementos e como o método tipológico e a composição de uma regulação contratual abstrata (de acordo com o que foi obtido anteriormente) podem auxiliar nessa fase hermenêutica de identificação do conteúdo do contrato. Essa primeira parte tenta responder às três primeiras questões apresentadas acima.

Por fim, para que possamos fazer a transição para a segunda parte do estudo, analisamos os possíveis índices dos tipos contratuais, apresentados como elementos identificadores distintivos de cada tipo contratual. Na pesquisa, desenvolvemos os índices mais importantes para a qualificação do tipo contratual da doação, a saber: (i) a gratuidade; (ii) a transferência patrimonial; (iii) a forma; (iv) a definitividade da transferência patrimonial; v) o caráter personalíssimo do contrato; (vi) o nomen dado pelas partes; e (vii) o animus donandi (fim ou causa contratual).

De posse dos resultados obtidos na primeira parte do presente estudo, acreditamos ser possível estabelecer alguns critérios para a composição do regime aplicável. Em primeiro 
lugar, a análise da causa de atribuição patrimonial permitirá evidenciar qual a natureza preponderante no negócio jurídico. Isto é, se predominantemente oneroso ou gratuito. Ademais, convém separar duas classificações distintas: entre contratos gratuitos e onerosos, de um lado, e contratos liberais e interessados, de outro. Embora comumente se tenha a identificação entre hipóteses de contratos gratuitos com atos liberais e, de outro lado, contratos onerosos com atos interessados (e.g. doação pura), nem sempre essa configuração estará presente. A inexistência da gratuidade, com a atribuição de obrigações para ambas as partes, pode, no entanto, retirar a qualificação do ato como doação, mas não evita a sua causa liberal (causa donandi). É o caso típico da compra e venda a preço irrisório (par franc symbolique).

Estudaremos especialmente três espécies de liberalidades atípicas: (i) o negotium mixtum cum donatione, frequentemente representado pela compra e venda a preço vil; (ii) o pagamento de dívida por terceiro em nome e por conta do devedor e a título de liberalidade; e (iii) as dádivas sociais, entendidas como sendo os presentes costumeiros, as esmolas, os dízimos religiosos e as gorjetas.

\section{2 - MÉTODO DA PESQUISA}

O método aplicado foi o dedutivo, partindo da hipótese de que a análise tipológica dos contratos pode ser útil para a construção do regime dos contratos atípicos, para, em seguida, aplicá-la ao contrato típico de doação e a figuras próximas.

O material pesquisado foi majoritariamente composto por artigos científicos, capítulos de obras coletivas e obras de juristas que analisaram o fenômeno no Brasil, em Portugal, Itália e França. Alguma referência é feita, esporadicamente, a autores alemães e a outros ordenamentos, como o argentino e os pertencentes à matriz de Common Law. Não pretendemos, contudo, tratar exaustivamente de todos os ordenamentos jurídicos, algo que seria impossível, dado o escopo da pesquisa. Também não aplicamos qualquer metologia pertencente ao Direito Comparado. As citações de doutrina estrangeira foram feitas em maior número quando o tema foi quantitativa e qualitativamente mais estudado do que no Brasil. Sempre que havia uma posição de algum autor brasileiro, ela teve preeminência face às demais ou foi reconduzida a algum autor estrangeiro que já havia sido citado. No primeiro título, sobretudo naquilo que dizia respeito à tipicidade contratual, demos preferência aos estudos realizados em Portugal e Itália. No segundo, aos oriundos de França e Itália. No terceiro, a doutrina italiana é majoritária devido à grande atenção dada ao negotium mixtum cum donatione nesse país. 
As fontes bibliográficas são oriundas de bibliotecas físicas, principalmente, das seguintes instituições: Biblioteca da Faculdade de Direito da Universidade de São Paulo (Largo São Francisco), Biblioteca do Ministério Público do Estado de São Paulo, Biblioteca da Faculdade de Direito da Universidade Jean Moulin - Lyon III, Biblioteca da Faculdade de Direito da Universidade Lumière - Lyon II, Biblioteca da Faculdade de Direito da Universidade Jean Monnet - Saint-Étienne, Biblioteca de Direito e Ciências Econômicas Cujas/Paris, Biblioteca da Universidade de Cergy-Pontoise, Biblioteca da Universidade Grenoble-Alpes, Biblioteca da Faculdade de Direito da Universidade de Coimbra.

Repositórios eletrônicos de artigos científicos, verbetes enciclopédicos e obras em domínio público, também foram utilizados, sobretudo oriundos de: Dalloz.fr, Lextenso.fr, Lexis360.fr, Jstor.com, HeinOnline, IusData, Google Livros, Archive.org, Gallica.bnf.fr, Hathitrust.org; Theses.fr; Academia.edu. Não foi feita referência quanto ao meio eletrônico ou físico da fonte consultada. Sempre que possível, a página em que se encontra o trecho ou a ideia citados na versão física foi indicada. Entretanto, certos repositórios eletrônicos apresentam versões sem paginação original correspondente, contendo apenas os elementos mínimos para a identificação da fonte original (fonte, data da publicação, página inicial). Nesses casos, esses elementos foram citados, ficando ausente, no entanto, a página específica.

A escolha das obras estrangeiras foi feita com base em razões práticas: (i) conhecimento mínimo da estrutura do ordenamento jurídico nos países citados; (ii) possibilidade de leitura, pelo pesquisador, das obras citadas no idioma original; (iii) facilidade de acesso a essas fontes. $\mathrm{O}$ recurso à doutrina alemã foi utilizado apenas quando estritamente necessário, levando em conta a falta de domínio adequado do idioma. Essa necessidade foi sentida, sobretudo, em duas ocasiões: (i) quando dois modelos teóricos eram tidos como arquétipos e pelo menos um deles teve seu desenvolvimento na Alemanha (e.g. no capítulo acerca das interpretações subjetiva e objetiva); (ii) quando a contribuição de um autor alemão para o tema repercutiu na discussão doutrinária brasileira a ponto de ser citada por quase todos os autores brasileiros que se dedicaram ao mesmo assunto (e.g. a contribuição de LUDWIG ENNECCERUS e HEINRICH LEHMANN para a classificação dos contratos coligados).

A apresentação das teses dos autores citados na pesquisa foi feita de maneira descritiva, com argumentos a favor ou contra sendo introduzidos apenas ao término da exposição sintética. Com isso, objetivamos dar ao leitor a possibilidade de conhecer a tese 
refutada, em todos os seus aspectos, evitando distorções das posições doutrinárias coletadas. Quando ideias pertencentes a dois autores foram contrastadas ${ }^{2}$, tomamos o cuidado de estabelecer, sempre que possível, padrões mínimos de concordância semântica a respeito do tema, sobretudo nos casos em que esses autores: (i) não pertenciam a uma mesma corrente de pensamento; (ii) não tinham por objeto de estudo o mesmo ordenamento jurídico; (iii) não estabeleceram um diálogo direto entre si. Esses padrões podem ser encontrados no corpo do texto ou em notas de rodapé e consistir em ressalvas quanto a pressupostos metodológicos ou a correntes perfilhadas pelos autores citados. Por essa razão, a leitura das notas de rodapé é essencial para a compreensão do texto.

\section{3 - FORMATO DAS CITAÇÕES DOUTRINÁRIAS}

Nas citações à doutrina, as referências aos autores foram feitas, preferencialmente, em letras maiúsculas no corpo do texto, adotando-se o nome completo. Excepcionalmente, quando conhecidos por uma ou mais parcelas do nome, adotou-se a denominação usual (e.g. PONTES DE MIRANDA, ENNECCERUS, ANTUNES VARELA). Em um mesmo parágrafo, para evitar a repetição desnecessária do nome de um autor, foi utilizado o substantivo comum com a primeira letra maiúscula (Autor ou Autora).

Para a citação das obras nas notas de rodapé e nas referências bibliográficas, adotamos as normas técnicas da ABNT, por reconhecermos a importância da uniformização da construção científica no país e a pequena probabilidade de repercussão internacional das pesquisas realizadas em língua portuguesa.

As citações das fontes romanas foram feitas tanto em latim quanto em português, sendo apresentadas no corpo do texto ou em notas de rodapé. As versões em latim do Digesto do IMPERADOR JUSTINIANO foram extraídas da décima quinta edição do Corpus Iuris Civilis editado por THEODOR MOMMSEN e PAUL KRUEGER ${ }^{3}$, reputada a melhor edição pela doutrina especializada ${ }^{4}$. Nas traduções para o português, utilizamos, quando possível, a versão de autoria do CONSELHEIRO MANOEL DA CUNHA LOPES VASCONCELLOS 5 . No entanto, os fragmentos que pertenciam aos livros do Digesto que

\footnotetext{
${ }^{2}$ Quando houve contraste entre ideias, sempre foi feito de modo explícito. Não se deve inferir da mera exposição em sequência dessas teses que haja algum diálogo entre os autores citados e seus posicionamentos.

${ }^{3}$ MOMMSEN, Theodor; KRÜGER, Paul. Corpus iuris civilis. 15. ed. Berlin: Weidmann, 1928, v. 1.

${ }^{4}$ MORAES, Bernardo B. Queiroz de. Manual de introdução ao Digesto. São Paulo: YK, 2017, p. 309.

5 VASCONCELLOS, Manoel da Cunha Lopes e (Conselheiro Vasconcellos) et alii. Digesto ou Pandectas do Imperador Justiniano. São Paulo: YK, 2017, v. 1; VASCONCELLOS, Manoel da Cunha Lopes e (Conselheiro Vasconcellos) et alii. Digesto ou Pandectas do Imperador Justiniano. São Paulo : YK, 2018, v. 3.
} 
ainda não foram publicados em versão portuguesa foram objeto de tradução livre baseada nas versões para o espanhol e o francês de GARCÍA DEL CORRAL e HENRI HULOT, respectivamente ${ }^{6}$. Do mesmo modo, no que diz respeito às traduções do Codex, a tradução para o português foi por nós realizada com base nas versões espanhola e francesa de GARCÍA DEL CORRAL ${ }^{7}$ e de PASCAL-ALEXANDRE TISSOT ${ }^{8}$, respectivamente. As citações das Institutas de GAIO foram extraídas da versão para o português de SEGURADO E CAMPOS e a versão latina não foi apresentada9.

As referências bibliográficas apresentadas ao final do trabalho estão em lista alfabética, sem repartição quanto à sua natureza (artigo científico, capítulo de livro ou obra). A listagem contém apenas as obras que são citadas no texto ou em notas de rodapé, embora outras possam ter sido eventualmente consultadas. A maioria dos autores é apresentada pelo último sobrenome, embora alguns apareçam na designação costumeiramente encontrada na doutrina brasileira (e.g.: PONTES DE MIRANDA, Francisco Cavalcanti; ANTUNES VARELA, João de Matos; COELHO DA ROCHA, Manuel António).

\section{4 - USO DE FONTES JURISPRUDENCIAIS}

Este estudo pretende-se predominantemente doutrinário e dogmático. Por essa razão, a citação de fontes jurisprudenciais é pouco utilizada, embora repute-se igualmente útil uma pesquisa empírica sobre o tema com base em julgados. Excepcionalmente, citamos algum julgado que pudesse ser elucidativo de alguma tese ou argumento apresentados. Nas passagens em que a doutrina francesa foi estudada, houve maior atenção à jurisprudência, sobretudo da Corte de Cassação francesa. A razão disso está em haver, em França, um tradicional diálogo entre jurisprudência, doutrina e legislativo, de sorte que um estudo da doutrina, sem a análise de casos, seria prejudicial para a compreensão das posições sustentadas pelos autores.

\footnotetext{
${ }^{6}$ GARCÍA DEL CORRAL, Ildefonso L. Cuerpo de derecho civil romano: digesto. Barcelona: Jaime Molinas, 1892, v. 2; GARCÍA DEL CORRAL, Ildefonso L. Cuerpo de derecho civil romano: digesto. Barcelona: Jaime Molinas, 1897, v. 3; HULOT, Henri Marie Joseph. Les cinquantes livres du Digeste ou des Pandectes de l'empereur Justinien. Metz: Behmer et Lamort, 1804, t. 2; HULOT, Henri Marie Joseph. Les cinquantes livres du Digeste ou des Pandectes de l'empereur Justinien. Metz: Behmer et Lamort, 1804, t. 3; HULOT, Henri Marie Joseph. Les cinquantes livres du Digeste ou des Pandectes de l'empereur Justinien. Metz: Behmer et Lamort, 1804, t. 6.

${ }^{7}$ GARCÍA DEL CORRAL, Ildefonso L. Cuerpo de derecho civil romano: código. Barcelona: Jaime Molinas, 1892, v. 4.

8 TISSOT, Pascal-Alexandre. Les douzes livres du Code de l'Empereur Justinien. Metz: Behmer, 1807, t. 2.

${ }^{9}$ GAIO. Instituições de direito privado romano. Tradução J. A. Segurado e Campos. Lisboa: Calouste Gulbenkian, 2010.
} 
Devido à escassez de julgados citados, não adotamos qualquer método para o recolhimento das fontes jurisprudenciais. Não houve escolha de metadados ou delimitação de base de dados a ser utilizada. Nenhuma análise qualitativa ou quantitativa com base em julgados foi feita ou serviu de argumento para as conclusões apresentadas. 


\section{CONCLUSÕES DO TÍTULO I}

1. Das diversas definições apresentadas, retivemos aquela que apresenta o tipo contratual como um modelo normativo socialmente reconhecível e suficiente para a composição do conteúdo contratual e sua regulação nos planos da existência, validade e eficácia do negócio jurídico. Por ser normativo, não se confunde, portanto, com a própria operação econômica que lhe é subjacente. Além disso, a suficiência da regulamentação é um requisito que distingue entre tipicidade e atipicidade.

2. O tipo contratual apresenta função supletiva, fornecendo regras dispositivas que complementam, em caso de lacuna, o regramento disposto pelas partes. Com isto, diminuemse também os custos de uma negociação acerca de todos os pontos do contrato, com as partes podendo concentrar-se apenas nas questões relevantes. Há, igualmente, certos tipos que apresentam parcelas de seu regime como cogentes e consolidam, destarte, certos valores caros ao sistema. Em sua maioria inspirados dos usos e costumes da prática contratual, os tipos podem ser interpretados à luz de seus modelos de referência, chamados tipos reais ou sociais. Além disso, a tipificação de um contrato requer uma decisão político-legislativa acerca da distribuição dos riscos na operação econômica subjacente.

3. Critica-se o uso dos tipos contratuais, reputando-o ultrapassado, pois as classes contratuais seriam mais adequadas a regerem a realidade complexa do mercado. Esquecese, contudo, que classes contratuais - ou tipos contratuais gerais - estão em plano distinto dos tipos contratuais. Aqueles estão a meio caminho das normas da teoria geral dos contratos e dos contratos em espécie; não regram suficientemente, portanto, a realidade contratual. Além disso, exigem a combinação tanto daquelas quanto destas, pois as classes ou tipos contratuais gerais são construídos para atuar mediante sobreposição ao regime típico. Ademais, tanto os tipos quanto as classes contratuais utilizam-se do método tipológico para inciderem sobre os contratos em concreto. A adoção destas não implicaria, portanto, o abandono daqueles.

4. Outra crítica, levantada por autores da corrente do Direito civil-constitucional, sustenta a superação do antigo modelo interpretativo baseado na subsunção, em que o intérprete seria visto como mero autômato, em favor de um suspostamente novo modelo de ponderação dos princípios, em que os tipos contratuais seriam meros esquemas de précompreensão da realidade. Essa crítica, entretanto, faz uma conexão entre constitucionalização do Direito e pós-positivismo que não se afigura necessária, tendo em 
vista ter havido doutrinadores que, muito antes do surgimento dessa corrente, já ressaltavam a necessidade de se relativizar a interpretação subsuntiva. Ademais, a necessidade de se utilizar do método tipológico para os casos fronteiriços não impede o reconhecimento da utilidade da subsunção para os casos paradigmáticos.

5. Também não se afigura correta a crítica que atribui aos tipos contratuais um papel de obstrução da atividade econômica, fazendo com que a criatividade fosse obstada diante da necessária recondução dos contratos a tipos legais. Essa crítica parte de uma análise que pressupõe a maior eficiência dos modelos de contratação dos países ligados à matriz Common Law, no que diz respeito a reduções de custos de transação. Entretanto, diversos estudos, mesmo quando feitos por autores que partem da Law and Economics, vem pondo em xeque essa suposta superioridade. Além disso, a uniformização do Direito contratual não parece indicar a prevalência de um modelo sobre o outro, mas uma convergência, ainda que essa assimilação correspectiva de distintas tradições de Direito dificilmente alcance um ponto ótimo que garanta o equilíbrio.

6. A tipificação é atribuição de tipos a certos fenômenos. O tipo é um modelo de representação da realidade que se distingue do conceito geral abstrato. Enquanto neste há um processo de abstração por indução e dedução, no tipo há um agrupamento do espaço amostral mediante semelhanças e dessemelhanças. O conceito, por isso, possui alta capacidade informativa, mas pouco descritiva. Em contraposição, o tipo é altamente descritivo, mas pouco informativo. Essa possibilidade de descrição faz com que o tipo seja mais adequado para representar situações complexas e casos fronteiriços entre um conceito e outro.

7. O tipo é: (i) aberto, pois não possui um elenco definitivo de características específicas; (ii) graduável, pois a semelhança entre os elementos pode ser maior ou menor; (iii) plástico ou elástico, permitindo abarcar não somente casos paradigmáticos, mas também frointeiriços; (iv) incompleto, pois depende de cada elemento representativo para ser informado; (v) estruturalmente unitário, sendo representação não só de cada um dos eventos que lhe são reconduzidos, mas também da relação destes entre si.

8. Os tipos contratuais podem se dividir, com relação à sua fonte, em (i) legais e (ii) sociais. A tipicidade social frequentemente aparece anteriormente à positivação do tipo contratual, que o transforma em tipo legal. É baseada na sedimentação e na força normativa dos usos e costumes. A tipicidade legal tem, não só um papel descritivo, mas também normativo, representando a vontade do legislador de regular um ou mais aspectos de 
determinada operação econômica. Não conferimos qualquer independência conceitual para a suposta tipicidade jurisprudencial, por reputá-la apenas como modo de reconhecimento de uma tipicidade social.

9. Em contraposição aos contratos típicos, há a possibilidade de se encontrarem contratos atípicos, expressamente reconhecida pelo ordenamento jurídico brasileiro (art. $425, \mathrm{CCB}$ ) e corolário do princípio da autonomia privada (ou da vontade). A atipicidade subdivide-se, por sua vez, em (i) pura, quando, para a sua formação, não se partiu de nenhum modelo regulatório legal como referência; e (ii) mista, formados mediante a composição de elementos pertencentes a contratos típicos distintos. Os contratos atípicos mistos aproximase dos tipos contratuais conhecidos mas não são suficientemente semelhantes para lhes serem reconduzidos. Apesar de certas críticas em relação à subdivisão, ela permanece útil, tendo em vista que o reconhecimento de um contrato como misto permite a seleção de regimes próximos aptos a serem utilizados na construção do modelo normativo aplicável.

10. Os contratos mistos diferenciam-se, ainda, dos contratos coligados. Estes últimos podem ser divididos em: (i) contratos coligados em sentido estrito, quando a coligação tiver por origem a Lei; (ii) contratos coligados por cláusula expressa, quando a fonte imediata for a vontade das partes; e (iii) contratos conexos, quando os contratos estiverem unidos por um nexo econômico, isto é, funcionarem como componentes de uma mesma operação econômica. Os contratos conexos, por sua vez, se subdividiriam em (iii.1) redes contratuais, quando houver relação de consumo; e (iiii.2) contratos conexos em sentido estrito, nos demais casos.

11. Nenhum dos critérios elencados pela doutrina para a distinção entre contratos mistos e conexos é suficiente, por si só, para essa tarefa. Devem ser utilizados em conjunto, reconhecendo que a causa contratual não é um elemento apto para, a priori, determinar se há unidade ou pluralidade de negócios. A compatibilidade entre regimes típicos é útil para distinguir e optar pela qualificação entre contrato misto ou coligado. Quando os regimes forem incompatíveis entre si, será preferível reconhecer um contrato misto, com um regime atípico. Por outro lado, havendo compatibilidade de regimes, a coligação contratual será mais provável. A incompatibilidade de regimes não deve, contudo, ser levada a extremos, de modo a sempre reputar que o contrato seja atípico, sobretudo levando em conta a existência de prestações principais e secundárias e a estrutura contratual. 
12. No que diz respeito ao regime a ser aplicado aos contratos mistos, as teorias comumente elecadas são: (i) absorção; (ii) combinação; (iii) analogia e (iv) criação. Nenhuma delas é suficiente para a construção do regime de todos os contratos mistos. Sendo este um problema eminentemente metodológico, deve-se ultrapassar a busca por um único critério e considerar as diversas teorias apresentadas como métodos que podem ser utilizados alternativamente, a depender da espécie de contrato misto identificada. Assim, temos que: (i) nos contratos de tipo modificado ou com tipo de referência, o método a ser aplicado será o da absorção, com incidência do regime preterido naquilo que for conciliável; (ii) nos contratos de tipo múltiplo, aplicar-se-á o método da composição, formando um regime atípico para o contrato misto a partir da combinação de dois ou mais regimes típicos; (iii) nos contratos de tipo múltiplo em que haja incompatibilidade de regimes típicos, o método a ser utilizado será o da analogia, partindo-se da própria declaração negocial e integrando-a mediante a incidência da boa-fé e dos usos e costumes.

13. A doutrina tradicional dividia os sistemas jurídicos em dois grupos de acordo com o método interpretativo dos contratos. Um grupo, cujo paradigma era o ordenamento francês, consagraria uma preponderância da vontade real das partes (interpretação subjetiva). Outro grupo, cujo principal modelo seria o alemão, daria maior valor à declaração das partes (interpretação objetiva). Analisando as diversas pesquisas sobre interpretação no Brasil, Alemanha e França das últimas décadas, percebemos que essa dicotomia é falsa. Há casos jurisprudenciais na Alemanha que deram maior importância à vontade real das partes (como se verifica no case da "carne de baleia"), assim como em França a jurisprudência dos "atos claros e precisos" dá contornos objetivos à interpretação contratual impedindo uma busca pela vontade das partes em casos simples.

14. Seguindo um modelo trifásico, conjugamos os dois métodos (interpretação subjetiva e objetiva) em duas fases interpretativas. A primeira, chamada "meramente recognitiva", buscaria formar uma pré-compreensão do significado do contrato através dos elementos subjetivos e daquilo que foi declarado pelas partes. A segunda, chamada “interpretação complementar”, usaria recursos objetivos para extrapolar e deduzir a vontade implícita das partes. Por fim, uma terceira fase se distinguiria da interpretação propriamente dita por não partir da vontade das partes como referencial. Seria uma integração do contrato mediante outras fontes, como a boa-fé e os usos e costumes.

16. Essa divisão do processo interpretativo será importante para determinar a separação dos índices contratuais responsáveis pela qualificação do contrato em dois grandes 
grupos: (i) índices subjetivos, de um lado, levados em consideração na primeira etapa interpretativa; e (ii) índices objetivos, de outro, utilizados durante a interpretação complementar.

17. A qualificação do contrato só pode ser feita através da identificação de seu sentido; este por sua vez é obtido mediante a atividade interpretativa. Por isso, a interpretação é pressuposto lógico da qualificação. A escolha dos meios interpretativos dependerá, portanto, do reconhecimento de determinado índice como subjetivo ou objetivo. 


\section{CONCLUSÕES DO TÍTULO II}

1. A classificação dos contratos em gratuitos e onerosos foi retraçada aos jusnaturalistas do século XVII, sobretudo a partir das obras de HUGO GRÓCIO e SAMUEL PUFENDORF, que se valeram da filosofia aristotélica, em que a justiça comutativa e o altruísmo eram virtudes, para uma fundamentação dos contratos consensuais. Ou seja, apesar da ausência de um formalismo, os contratos onerosos mereciam tutela jurídica por serem representativos da justiça comutativa, ao passo que os gratuitos eram expressão da virtude aristotélica do altruísmo.

2. No entanto, o progressivo despreendimento da filosofia aristotélica da divisão dos contratos em gratuitos e onerosos fez com que a doutrina posterior, sobretudo nos séculos XVIII e XIX, desenvolvesse a teoria da causa, apresentando uma causa para os contratos onerosos, qual seja, a contraprestação, e identificando a ausência de contraprestação ou a própria liberalidade como causa dos contratos gratuitos. Essa formulação pôde ser vista ainda na obra de JEAN DOMAT. Desde então, a classificação tradicional dos contratos em onerosos e gratuitos baseou-se na presença ou ausência de vantagens (ou sacrifícios) para ambos os contratantes. A doutrina do final do século XIX, no entanto, percebeu que esse critério era insuficiente sobretudo para a qualificação da doação quando nela se incluía um encargo, já que este poderia ser entendido como uma vantagem para o doador.

3. Diversos critérios alternativos apresentados pela doutrina foram estudados. O mais importante foi apresentado pela doutrina italiana e conjugava, na verdade, dois elementos. Um primeiro elemento, objetivo, seria a ausência de um equivalente econômico ao bem doado (avaliação econômica). Um segundo elemento, subjetivo, seria o fato de o doador não considerar o encargo como equivalente à sua prestação (avaliação subjetiva). Estudamos, de um ponto de vista jurídico e pragmático, os inconvenientes de se analisar o valor do encargo sob a perspectiva dos próprios contratantes. $\mathrm{O}$ valor da doação, para as partes ao contrato, depende de fatores extrajurídicos. Um certo bem, de pouco valor econômico, pode ter grande valor para o donatário dependendo de quem tenha sido o doador, e vice-versa. A incerteza do critério, de um ponto de vista prático, não resolve a incerteza jurídica na qualificação do contrato.

4. Outros critérios que não alcançaram uma grande adesão da doutrina também foram estudados. Em França, mais recentemente, JUDITH ROCHFELD apresentou o critério da racionalidade. Os contratos gratuitos teriam uma causa contratual irracional, pois a 
existência e o valor da contraprestação seriam incertos. A verificação da irracionalidade era realizada pela autora através de uma série de indícios e presunções. A existência de laços de parentesco ou de amizade, por exemplo, indicariam gratuidade. Por outro lado, a equivalência econômica do bem doado e do encargo indicariam onerosidade. No entanto, o encargo não adquire contornos seguros para a qualificação do contrato no modelo da Autora, pois ROCHFELD indica que tudo dependerá de ser, ele, a finalidade principal do contrato de doação, supondo portanto uma pesquisa dos motivos dos contratantes. A principal dificuldade de qualificação do contrato de doação permaneceu sem solução. A Autora conseguiu, no entanto, ressaltar indícios importantes para a gratuidade, mas dificultou a resolução do problema ao incluí-los, todos, em um único critério qualificador da doação, qual seja, a gratuidade.

5. Após analisarmos as doutrinas brasileira, francesa, italiana e portuguesa, concluímos que nenhuma alternativa ao critério tradicional da ausência de vantagem permite esclarecer a distinção entre contratos gratuitos e onerosos. Na verdade, a crítica principal ao critério tradicional só tem sentido se assumirmos o pressuposto de que a qualificação do contrato deva ser feita através do método conceitual-subsuntivo, ou seja, considerando que um único elemento deva ser necessário e suficiente para o reconhecimento da doação.

6. Mesmo os autores que salientam a necessidade de se trabalhar com indícios e presunções, recorrem, ao fim e ao cabo, a um único critério. Foi o caso de JUDITH ROCHFELD, em França, ANTUNES VARELA, em Portugal, e AGOSTINHO ALVIM, no Brasil. Portanto, parece ser preferível encarar os indícios apresentados pela doutrina como índices do contrato de doação independentes e tão relevantes quanto a gratuidade, mas que com ela não devem ser confundidos. Na dúvida, caso os demais índices de qualificação não permitam uma solução, a opção entre onerosidade e gratuidade deve ser feita em benefício da primeira, por apresentar um regime jurídico mais equilibrado para ambos os contraentes.

7. Após o estudo da gratuidade, analisamos o objeto do contrato como possível índice de qualificação da doação. Em um plano de teoria geral do contrato, verificamos as doutrinas que tentaram classificá-los exclusivamente de acordo com o objeto. Nesse grupo encaixavase MARCEL PLANIOL, que identificou três classes de contratos (contratos de trabalho, de direitos e de coisas). Percebemos a dificuldade em se encaixar certos tipos contratuais nessa classificação, sobretudo contratos mistos e policausais (que admitem a qualificação de diversos tipos para uma mesma operação, como a cessão de crédito, que pode ser onerosa ou gratuita). Com o mesmo objetivo, ANNE-SOPHIE LUCAS-PUGET também tentou 
classificar os contratos de acordo com o objeto, mas teve de redefini-lo como interesse contratual e acabou desnaturando o conceito jurídico de objeto, abrangendo a causa contratual. A própria Autora chegou a reconhecer que os casos tradicionalmente reputados como aplicações da causa passavam, com a redefinição do objeto do contrato, a serem abarcados por este último.

8. A análise dessas doutrinas conduziu-nos à conclusão de que o objeto também não pode ser esse elemento essencial que o método conceitual-subsuntivo procura para qualificação dos contratos. No entanto, pode vir a ser útil como índice de qualificação, sobretudo para distinguir subtipos de doações. A distinção entre doação de bens móveis e imóveis é baseada no objeto e permite uma separação de regimes com relação à forma contratual necessária. Igualmente, a doação mediante subvenções periódicas permite afastar a necessidade de transferência patrimonial imediata, caracterizando um contrato consensual.

9. Além disso, o objeto do contrato de doação deve ligar-se à noção de transferência patrimonial definitiva. É a ideia de irrevogabilidade (donner et renetir ne vaut), que tradicionalmente esteve atrelada ao regime da doação e que permite distingui-la do mútuo e do mandato. $\mathrm{O}$ índice da transferência patrimonial também possibilita distanciar a doação das hipóteses de prescrição e usucapião. À primeira vista, a indagação parece não ter cabimento, haja vista que ambas as hipóteses nem sequer são espécies contratuais. Contudo, sabendo que alguns dos exemplos apresentados pela doutrina como doações indiretas não são contratos (e.g. pagamento de dívida alheia e remissão de dívida), é natural que a dúvida possa surgir em relação a outros atos supostamente prejudiciais ao titular de um direito e que beneficiam uma terceira pessoa, como a prescrição e a usucapião.

10. Partindo novamente da premissa de que o método conceitual-subsuntivo possa ser aplicado, tentamos verificar se a forma poderia ser considerada elemento essencial do contrato, permitindo, por si só, sua identificação como doação. Na doutrina, encontramos as posições sobretudo de GINO GORLA na Itália, GEORGES ROUHETTE em França, e LUCIANO DE CAMARGO PENTEADO no Brasil. Todos os três acreditavam que a forma seria causa categorial da doação, distinguindo-a dos contratos onerosos.

11. Uma análise histórica dos motivos pelos quais a doação é um contrato solene nos permitiu concluir que a formalidade das doações é um atributo de política legislativa e, portanto, discricionária, dependendo das necessidades de certa época e sociedade. As primeiras solenidades, ainda no Império Romano, a começar pela lex Cincia de numeribus 
(204 a.C.), indicam que as formalidades foram inicialmente uma forma de impedir doações a patronos e oradores, que deveriam supostamente advogar gratuitamente pelas causas de seus clientes. Era uma forma de controle do fluxo patrimonial. Outras razões mais efêmeras também são apontadas pelos historiadores, como as Guerras Púnicas e a tentativa de se controlar o dispêndio de patrimônio durante períodos de escassez de recursos.

12. O formalismo contemporâneo das doações teve seu germe na Ordonnance de 1731 de D'AGUESSEAU, em França. Documentos históricos registram que o objetivo do próprio Chanceler ao dar contornos solenes à doação era o de garantir a irrevogabilidade da transferência patrimonial. Atualmente, a doutrina majoritária, mesmo no Brasil, afirma que a formalidade do contrato de doação é para acautelar o doador acerca de um ato potencialmente prejudicial a seu patrimônio. Vê-se que as razões para as formalidades variaram muito e não garantem um elemento constante o suficiente para qualificar o contrato. Além disso, diversos ordenamentos passaram a “desolenizar" a doação. No Brasil, a exigência de instrumento escrito é mitigada por diversas exceções e ela é tida como ato de pequena formalidade. Em França, a categoria das doações indiretas serviu de fuga ao regime rígido dos atos autênticos. Percebe-se, portanto, uma tendência à flexibilização da forma solene para as doações.

13. Verificamos, em seguida, que o tempo pode vir a ser um índice importante da doação em conjunto com outros mais relevantes. A qualificação do subtipo de doação por subvenções periódicas, por exemplo, depende dessa regularidade nas prestações marcadas pelo fator temporal. Ademais, a irrevogabilidade das doações demonstra que a transferência é definitiva e imediata, salvo na hipótese das subvenções peiódicas. Assim, o fator temporal permite distinguir a doação de contratos que tenham por objeto cessão temporária de uso, como o mútuo e o comodato.

14. Indicada por alguma doutrina como indício de gratuidade, a qualidade das partes pode ser relevante na qualificação da doação quando existentes laços de parentesco ou amizade. É difícil estabelecê-la como critério suficiente para a qualificação. Deve-se lembrar que o método aplicado não é conceitual-subsuntivo, mas tipológico, exigindo portanto um conjunto de índices. Nos casos em que haja dúvida entre gratuidade e onerosidade, o índice de qualidade das partes poderá servir para escolher entre ambas as categorias. Nesse ponto, há subsídios inclusive da antropologia, cujos estudos acerca da doação tiveram grande impulso a partir de MARCEL MAUSS, que apontou para uma necessidade de retribuição dos presentes e outros bens doados ainda em sociedades primitivas. A análise de regimes 
jurídicos do contrato de doação ocidentais confirma essa visão, notadamente com relação às hipóteses de ingratidão do donatário e revogação por ingratidão da doação. Por isso, o ato de doar, mesmo primitivamente, era visto como criador de vínculos entre doador e donatário que ultrapassavam a liberalidade e permaneciam entre as partes.

15. A denominação dada pelas partes ao contrato é tradicionalmente subestimada pela doutrina. Em hipóteses de difícil qualificação, quando todos os demais índices falharem, não parece haver razão para ignorar a qualificação voluntária. No caso da doação, a qualificação pelas partes pode justificar uma presunção relativa acerca da natureza gratuita do contrato. Isto porque os regimes dos contratos gratuitos são mais rígidos do que os dos contratos onerosos em diversos aspectos. Seja na fraude contra credores, em que se impede a proteção do adquirente de boa-fé, seja na regra interpretativa que restringe as obrigações do doador face ao donatário, seja ainda nas regras referentes à revogação e à redução das liberalidades, diante de uma livre escolha entre a incidência dos regimes de contratos onerosos ou gratuitos, as partes, quando cientes dessa diferença, certamente optariam por uma qualificação contratual que afastasse as regras pertinentes aos contratos gratuitos. Dificilmente, portanto, uma qualificação voluntária do contrato como doação será feita com intento fraudulento.

16. Quando os demais índices, portanto, não fornecerem uma resposta segura e a escolha de qualificação, pelo intérprete competente, restar entre um tipo contratual oneroso e um tipo contratual gratuito, a denominação dada pelas partes deverá ser levada em conta. Em primeiro lugar, por um respeito à liberdade contratual quanto às possíveis escolhas. Em segundo lugar, porque a opção pela gratuidade, por um lado, dificilmente mascara um contrato verdadeiramente oneroso e, ainda, porque a opção pela onerosidade, por outro, privilegia um regime que atende aos interesses de ambos os contratantes.

17. A doutrina que nega papel relevante ao animus donandi tem dificuldade em qualificar certas figuras contratuais. AGOSTINHO ALVIM, por exemplo, afirmava que apenas a gratuidade era suficiente. Isso não lhe impediu, contudo, de utilizar diversas vezes o critério do animus donandi para distinguir certas figuras próximas da doação. Assim, por exemplo nas hipóteses de usucapião ou prescrição, indicava faltar animus donandi. Igualmente, nas vendas a preço vil e nas gratificações dadas pelo empregador ao empregado. A principal dificuldade da doutrina que nega aplicação ao animus donandi está em encontrar um critério apto a distinguir casos fronteiriços, como as doações indiretas, dádivas, liberalidades costumeiras e atos gratuitos com escopo comercial. O problema cresce quando se percebe que há ordenamentos em que muitas dessas figuras escapam do formalismo das 
doações com o apoio da doutrina, jurisprudência e, menos frequentemente, do legislador. Se a forma fosse, de fato, causa civil da doação, ela não poderia faltar nas hipóteses de doação indireta reconhecidas em França e Itália. Embora o critério do animus donandi não solucione os casos típicos da doação pura e simples, parece ser útil para a distinção das "liberalidades atípicas".

18. Se há dificuldade em definir o animus donandi sem que aparente tratar-se de tautologia, pode-se utilizá-lo com índice negativo. Dessa forma, quando afastada a possibilidade de existir animus donandi no contrato em concreto, como nas compras e vendas a preço menor com escopo lucrativo, não haverá semelhança do negócio com o tipo da doação. 


\section{CONCLUSÕES DO TÍTULO III}

1. A doação é uma espécie do gênero das liberalidades. Caracteriza-se, sobretudo, pelo seu aspecto contratual e por ser o caso paradigmático do tipo contratual gratuito. No entanto, não esgota a realidade dos atos liberais. As liberalidades atípicas, ou doações indiretas, são aquelas cujos efeitos assemelham-se aos da doação, embora o ato praticado não possua índices suficientes para ser reconduzido ao seu regime típico.

2. O negotium mixtum cum donatione é talvez a principal figura do grupo das liberalidades atípicas e costuma ser representado pelo paradigma da compra e venda a preço vil. Uma parcela considerável da doutrina reputa tratar-se de negócio jurídico indireto, afirmando que a gratuidade que surge como efeito do negócio é mero motivo. Entretanto, a desproporção no sinalagma que permite que ocorra a atribuição patrimonial gratuita faz parte da estrutura do negócio. Além disso, tipologicamente, já vimos que a forma não é um índice do contrato de doação e, portanto, os requisitos formais desse contrato não se aplicam às demais liberalidades por analogia. De sorte que não há necessidade de se recorrer à figura do negócio jurídico indireto para explicar o afastamento das solenidades aplicáveis às doações.

3. O negotium mixtum cum donatione também não se confunde com a doação com encargo. Naquele, há onerosidade predominante, enquanto neste a gratuidade prevalece. A doação com encargo é subtipo da doação e, portanto, o regime típico incide por completo, salvo quando houver norma em sentido contrário. Por outro lado, o negotium mixtum é liberalidade que escapa do tipo da doação e só recebe a incidência de seu regime típico por analogia.

4. Uma outra corrente doutrinária identifica o negotium mixtum cum donatione como espécie de contrato misto, aplicando-lhe o método da combinação de regimes por acreditar haver uma causa mista, parcialmente onerosa e gratuita. De fato, a combinação de atribuições patrimoniais com causas diversas parece atrair a qualificação de contrato misto para a figura do negotium mixtum cum donatione. Entretanto, a cisão artificial das prestações em partes gratuita e onerosa desrespeita a estrutura unitária do contrato e utiliza critérios arbitrários para a tarifação de um preço supostamente justo. Por isso, o regime a ser aplicável deve incidir sobre o contrato como um todo. Assim, ainda que obtido pelo método da combinação, esse regime não pode repartir as prestações em violação da unidade que elas apresentam. 
5. No entanto, como os regimes dos contratos onerosos são incompatíveis com o dos gratuitos, o método a ser aplicado para a obtenção do regime do negotium mixtum cum donatione só pode ser o da analogia. No entanto, o intérprete deve se pautar por uma máxima de que a construção do regime não poderá operar uma repartição do contrato, de modo a aplicar uma tarifação da prestação, como no caso do preço justo. Isso significa dizer que as normas que digam respeito à própria fonte contratual, sobretudo aquelas de extinção (anulação, resolução, revogação), devem ser aplicadas no contrato como um todo. Por outro lado, as normas acerca das atribuições patrimoniais podem, em último caso, ser aplicadas apenas na parte gratuita ou onerosa. Sempre que possível, contudo, uma norma única para todos os efeitos do contrato, que não desrespeite a mitigação do sinalagma, será preferível.

6. No que diz respeito à ação pauliana, o art. 158 do CCB será aplicável ao negotium mixtum cum donatione, ao invés do art. 159 do CCB, pois o âmbito de incidência daquela norma é maior, abrangendo todos os "negócios de transmissão gratuita de bens ou remissão de dívida". Destarte, não há necessidade de se provar o consilium fraudis. Entretanto, o comprador-donatário poderá obstar a ação oferecendo-se a pagar o suplemento do preço, com base no valor de mercado da coisa.

7. Por outro lado, o instituto da lesão não é compatível com o negotium mixtum cum donatione. Enquanto, naquele, a desproporção entre as prestações é causa de anulabilidade; neste, é causa de atribuição patrimonial a título gratuito. A distinção entre as duas figuras não deve, contudo, partir de uma tarifação da lesão (ultra dimidium iustii pretii), como alguns autores sugerem. A transposição da tarifação da lesão para a verificação da validade do negotium mixtum cum donatione implica em novamente tentar separar partes onerosa e gratuita do contrato, aplicando a teoria da separação.

8. O critério da desproporção manifesta de valores deve ser utilizado para a caracterização tanto da lesão quanto do negotium mixtum cum donatione. A distinção entre as figuras deverá ser feita mediante critérios adicionais. Para isso, os demais índices do contrato de doação podem servir de auxílio. Uma relação de parentesco ou amizade entre as partes, por exemplo, pode indicar tratar-se de um negotium mixtum cum donatione. A existência de uma finalidade que afaste o animus donandi, por outro lado, indicaria tratar-se de lesão.

9. Como o fundamento do regime dos vícios redibitórios é a preservação do sinalagma no momento da execução do contrato, a garantia também deve ser reconhecida para o negotium mixtum cum donatione, que, a despeito de sua atipicidade, apresenta um sinalagma 
mitigado. Ademais, se à doação com encargo, subtipo que mais se aproxima do negotium mixtum, é aplicável o regime dos vícios redibitórios, com maior razão será aplicável ao negotium mixtum cum donatione. Por aplicação do art. 540 do CCB, permite-se, nesse caso, a cisão do negócio de modo a ser possível a redução do preço na ação estimatória. Contudo, parte da atribuição patrimonial é gratuita, mas não sabemos qual é o valor que corresponde a essa gratuidade, sob pena de a avaliação acerca da equivalência das prestações feita pelas partes ser desprezada. Por isso, apenas quando o valor da coisa viciada for inferior àquele da contraprestação é que será possível a redução do preço pago. O método para o cálculo permanece sendo aquele proporcional e não contraria o sinalagma genético, tal como estabelecido pelas partes, pois a proporção original leva em consideração tanto a parte gratuita quanto a onerosa. Por outro lado, naquilo que pertine à ação redibitória, a restituição deve levar em consideração o preço integralmente pago, assim como a coisa entregue. Isso se dá pois a redibição opera no plano da eficácia, resolvendo o negócio com eficácia ex tunc. Há, portanto, o desaparecimento da própria causa de atribuição patrimonial, seja da parte gratuita, seja da onerosa, com a extinção do contrato.

10. A garantia contra evicção também é aplicável ao negotium mixtum cum donatione. Se a evicção for total, restituir-se-á o preço integralmente pago, incluindo os acessórios indicados pelo art. 450, CCB, em seus incisos, pois a alegação de parcial gratuidade não poderá ser invocada face ao evictor, terceiro de boa-fé. No entanto, se a evicção for parcial, solução semelhante àquela apresentada para os vícios redibitórios deve ser aqui adotada. Se a evicção for parcial, caberá descobrir se ela é considerável ou não. Na primeira hipótese, o evicto tem a alternativa entre a rescisão (rectius, resolução) do contrato e a restituição do "preço correspondente ao desfalque sofrido". Caso opte pela resolução, a restituição será integral, regida pela norma do art. 450 do CCB, pois retira-se a causa de atribuição patrimonial por inteiro com a extinção do contrato. Do contrário, optando pela restituição de parte do preço, o desfalque sofrido deve ser considerado em relação ao preço originalmente pago e o valor da coisa recebida, como já havia sido apresentado para os vícios redibitórios. Assim, se o desfalque não desvalorizar a coisa abaixo do preço pago, não haverá restituição alguma. Nesse caso, o evicto não terá outra opção a não ser ficar com a coisa ou restituí-la mediante a devolução do preço pago. Por outro lado, se o desfalque for suficiente a ponto de o valor da coisa tornar-se inferior ao preço pago, poderá ser exigida restituição proporcional em relação àquela estabelecida pelas partes entre o valor da coisa e o preço acordado no contrato. Na segunda hipótese, não sendo considerável a evicção parcial, o evicto não possui a alternativa de resolver o contrato, podendo exigir somente a indenização, conforme dispõe 
a parte final do art. 455 do CCB. Essa indenização deverá observar os mesmos requisitos da primeira hipótese, (i) verificando se a diminuição de valor foi inferior ou não ao preço; e, em caso afirmativo, (ii) reduzindo-o na proporção originariamente estabelecida pelas partes.

11. Sendo um dos principais índices a caracterizar o negotium mixtum cum donatione, o aspecto personalíssimo da contratação atrai a parcela do regime do contrato de doação referente à revogação por ingratidão. Por ser aplicação analógica e pela aproximação que possui em relação à doação com encargo, o regime aplicável ao negotium mixtum deve levar em conta as exceções à revogabilidade que incidem sobre aquela figura. Assim, caso as prestações já tenham sido executadas, a revogação não poderá mais ser realizada, por aplicação analógica da disposição que veda a revogação por ingratidão nas hipóteses em que o encargo já tenha sido cumprido. Considerando, ainda, que o contrato deve ser percebido como um todo incindível e, por conseguinte, seu regime deve se aplicar inteiramente, a revogação, quando possível, atingirá o contrato em sua inteireza.

12. O negotium mixtum cum donatione está, ainda, sujeito à colação. Devendo esta ser feita por valor, assim como determina a regra geral no sistema jurídico brasileiro. Tendo vista que o objetivo da colação é a preservação da legítima, há uma preocupação em relação ao empobrecimento do doador. Portanto, o valor a ser colacionado deve ser aquele que efetivamente correspondeu a um empobrecimento do autor da herança. No caso do negotium mixtum cum donatione, esse valor corresponde à diferença entre o valor de mercado da coisa objeto do contrato e o preço pago pelo comprador-donatário.

13. A estipulação em favor de terceiro também pode vir a configurar uma liberalidade atípica. Há, na estipulação em favor de terceiro, uma atribuição patrimonial indireta, do promissário ao beneficiário, mediante o patrimônio do promitente, que pode ser donandi ou credendi causa. Há um certo nexo de causalidade entre o empobrecimento do estipulante e o enriquecimento do beneficiário ao se considerar que o custo da atribuição patrimonial recebida pelo beneficiário é "suportado" pelo estipulante. Em decorrência da estrutura triangular, a atribuição patrimonial realizada pelo promissário ao promitente pode diferir daquela feita pelo promitente ao beneficiário. O valor a ser considerado na colação, redução e imputação das liberalidades deve ser aquele correspondente ao efetivo empobrecimento do promitente, devido ao fundamento desses institutos ser a preservação da legítima. Por outro lado, a revogação da liberalidade fulmina a própria fonte contratual, razão pela qual nenhuma atribuição patrimonial pode subsistir. 
14. Como a forma da doação não se constitui em índice do tipo contratual, ela não afasta a incidência das demais regras nesse contrato a despeito de não ser observada. Além disso, a observância ou não da forma imposta às doações simples não é um problema referente à relação de valuta, mas à relação de cobertura. De sorte que ser ou não uma doação indireta não importa para determinar a validade, quanto à forma, da estipulação em favor de terceiro. Ainda que fosse relevante, a recusa em se reconhecer a formalidade como índice do contrato de doação seria bastante para afastar as solenidades desse tipo contratual.

15. O pagamento de dívida alheia pode vir a consistir em uma liberalidade atípica quando feito por conta e em nome do devedor. Mesmo nessa hipótese, contudo, não há presunção de liberalidade. Deve esta ser provada. Assim, deve-se afastar a existência de outra relação jurídica subjacente que justifique o pagamento pelo terceiro. Este pode ser, por exemplo, mandatário ou gestor de negócios do devedor. A transferência patrimonial obtida mediante uma operação triangular, quando identificada como gratuita, é um importante índice da doação. Deve, ainda, haver acordo acerca da causa de atribuição patrimonial. Esse acordo pode ser afastado quando houver oposição expressa do devedor contra o adimplemento pelo terceiro. A revogação por ingratidão não incide, contudo, nessa hipótese de liberalidade atípica em virtude de a fonte da atribuição patrimonial não possuir natureza contratual.

16. As dádivas costumeiras são outra espécie de liberalidade atípica cuja natureza jurídica é objeto de debate doutrinário. Incluem-se nesse grupo os donativos a associações, fundações e igrejas; as esmolas; os presentes em datas especiais e as gorjetas. Uma parcela da doutrina considere tratar-se de adimplemento de dever moral que, por conseguinte, afastaria o animus donandi. No entanto, entendido este em seu sentido negativo, como ausência de outra relação jurídica ou finalidade com ele incompatível, a justificativa não se sustenta. Há, ainda, autores que baseiam-se na separação entre Moral e Direito, reputando tratar-se de atos pertinentes ao primeiro campo e, portanto, "extrajurídicos". Essa postura ignora que o Direito frequentemente se interessa por esses atos, seja para definir o contrato de doação de maneira negativa - isto é, aquilo que não é doação — seja para fins tributários ou trabalhistas (no caso das gorjetas). Por essa razão, há relevância jurídica das dádivas cuja fonte normativa são os usos e costumes.

17. Para que uma dádiva possa ser reconhecida, alguns requisitos devem estar presentes. Primeiro, uma atribuição patrimonial gratuita. Segundo, essa atribuição deve ser módica quando comparada ao patrimônio do dador. Terceiro, não pode tratar-se de bem 
imóvel. Quarto, deve haver um uso ou costume que seja com ela compatível. Por essa razão, concluímos que as dádivas são socialmente típicas, afastando por completo o regime do contrato de doação. 


\section{CONCLUSÕES FINAIS}

1. A análise tipológica mostrou-se útil para a qualificação do contrato de doação. Percebemos que a forma não serve como índice do contrato, pois não há nenhum fundamento relacionado à sua natureza que a imponha. Como índices, verificamos a utilidade: (i) do caráter gratuito, entendido em seu sentido tradicional; (ii) do animus donandi, em acepção negativa; (iii) da qualidade das partes; (iv) da definitividade da transferência patrimonial; e (v) da denominação voluntariamente dada ao contrato pelas partes.

2. Os critérios de identificação de contratos coligados e mistos foram úteis para encontrar a natureza do negotium mixtum cum donatione. Concluímos tratar-se de contrato misto cujo regime deve ser obtido a partir do método analógico, levando em consideração a unidade do contrato. A partir dessa premissa, obtivemos um regime jurídico aplicável no que diz respeito a: (i) fraude contra credores; (ii) lesão; (iii) vícios redibitórios; (iv) eviç̧ão; (v) forma; (vi) revogação por ingratidão; e (vii) colação e redução das liberalidades.

3. Consideramos que a transferência patrimonial gratuita e a sua definitividade são índices aptos a qualificar, em alguns casos, a atribuição patrimonial feita mediante estipulação em favor de terceiro como liberalidade atípica, fazendo incidir algumas das regras da doação.

4. Os mesmos índices foram relevantes para encontrar as situações em que o pagamento de dívida alheia seria uma liberalidade atípica. Além daqueles aventados para a estipulação em favor de terceiro, as relações de parentesco ou amizade também se mostraram importantes.

5. As dádivas foram qualificadas como contratos socialmente típicos, cujo regime é mínimo e afasta por completo as regras do contrato de doação. Alguns requisitos para o reconhecimento das dádivas foram apresentados: (i) atribuição patrimonial gratuita; (ii) uso ou costume social; (iii) bem móvel de valor módico comparado ao patrimônio do dador; (iii) conformidade da atribuição ao uso social ou costume, mediante verificação das circunstâncias negociais. 


\section{BIBLIOGRAFIA}

ALMEIDA, Carlos Ferreira de. A doação e a dádiva. Themis, Lisboa, ano 9, n. 17, p. 5$18,2009$.

. Contratos III: contratos de liberalidade, de cooperação e risco. 2. ed. Coimbra: Almedina, 2015.

ALPA, Guido; ZENO-ZENCOVICH, Vincenzo. Italian private law. New York: Routledge-Cavendish, 2007.

ALVIM, Agostinho. Da doação. São Paulo: Revista dos Tribunais, 1963.

AMARAL, Francisco. Direito civil: introdução. 7. ed. rev., mod. e aum. Rio de Janeiro: Renovar, 2008.

AMRANI-MEKKI, Soraya. Indivisibilité et ensembles contractuels : l'anéantissement en cascade des contrats. Defrénois, Lextenso, n. 6, p. 355 e ss., mar. 2002.

ANCEL, Pascal. Force obligatoire et contenu obligationnel du contrat. Revue Trimestrielle de Droit Civil, Paris, Dalloz, n. 4, p. 771 e ss., 15.12.1999.

ANDRADE, Darcy Bessone de Oliveira. Do contrato: teoria geral. Rio de Janeiro: Forense, 1987.

ANDRADE, Fabio Siebeneichler de; BARTH, Guilherme Bertotto. Notas sobre a atualidade dos contratos atípicos e sobre a sua relação com os (novos) princípios contratuais nos dez anos de vigência do Código Civil brasileiro. In: CASTRO, Matheus de; PEZZELLA, Maria Cristina Cereser; RECKZIEGEL, Janaína (Org.). A Ampliação dos direitos subjetivos no Brasil e na Alemanha. t. 2. Joaçaba: Unoesc, 2013, p. 249-262.

. Os contratos atípicos como expressão da autonomia privada na esfera negocial. In: ESTEVEZ, André Fernandes; JOBIM, Marcio Felix (Org.). Estudos de direito empresarial: homenagem aos 50 anos de docência do Professor Peter Walter Ashton. São Paulo: Saraiva, 2012, p. 267-287.

ANTUNES, José Engrácia. Os usos e o costume no direito comercial: algumas breves reflexões. In: AMARAL, Diogo Freitas do; ALMEIDA, Carlos Ferreira de; ALMEIDA, 
Marta Tavares de (coord.). Estudos comemorativos dos 10 anos da Faculdade de Direito da Universidade Nova de Lisboa. Coimbra: Almedina, 2008, v. 2, p. 215-239.

ANTUNES VARELA, João de Matos. Das obrigações em geral. 10. ed. Coimbra: Almedina, 2013, v. 1.

. Das obrigações em geral. 7. ed. Coimbra: Almedina, 2012, v. 2.

. Contratos mistos. Boletim da Faculdade de Direito, Universidade de Coimbra, Coimbra, n. 44, 1968.

. Ensaio sobre o conceito do modo. Coimbra: Atlântida, 1955.

ARISTOTLE. Nicomachean ethics. Tradução Roger Crisp. Cambridge: Cambridge University Press, 2004.

ASCARELLI, Tullio. Negócio jurídico indirecto. Lisboa: Jornal do Foro, 1965.

. Contrato misto, negócio indireto, 'negotium mixtum cum donatione'. Revista dos Tribunais, ano 101, v. 925, p. 27-43, nov. 2012.

. O conceito unitário do contrato de seguro. Revista da Faculdade de Direito da Universidade de São Paulo, São Paulo, v. 36, n. 3, p. 388-437, 1941.

ASCENSÃO, José de Oliveira. Direito civil: teoria geral. 3. ed. São Paulo: Saraiva, 2010, v. 2.

. Direito civil: teoria geral. 2. ed. São Paulo: Saraiva, 2010, v. 3.

. Alteração das circunstâncias e justiça contratual no novo Código Civil. Revista CEJ, n. 25, p. 59-69, abr./jun. 2004.

. A tipicidade dos direitos reais. Lisboa: s.e.c., 1968.

ASCOLI, Alfredo. Trattato delle donazioni. Firenze: Fratelli Cammelli, 1898.

AUBERT, Jean-Luc; DUTILLEUL, François Collart. Le contrat: droit des obligations. Paris: Dalloz, 2017. 
AUBRY, Charles; RAU, Charles. Cours de droit civil français d'après l'ouvrage allemande de C.-S. Zachariae. Paris: Imprimerie et librairie générale de jurisprudence, 1856, t. 3 .

AUDIT, Bernard. L'américanisation du droit: introduction. Archives de Philosophie du Droit, Paris, v. 45, p. 7-11.

AZEVEDO, Álvaro Villaça. Contratos inominados ou atípicos. São Paulo: Bushatsky, 1975.

AZEVEDO, Antonio Junqueira de. Negócio jurídico: existência, validade e eficácia. 4. ed. São Paulo: Saraiva, 2002.

Negócio jurídico e declaração negocial: noções gerais e formação da declaração negocial. Tese (Titularidade), Faculdade de Direito da Universidade de São Paulo, São Paulo, 1986.

Interpretação do contrato pelo exame da vontade contratual. In:

Estudos e pareceres de direito privado. São Paulo: Saraiva, 2004, p. 159-172.

. Cláusula cruzada de não indenizar (cross-waiver of liability), ou cláusula de não-indenizar com eficácia protetiva para ambos os contratantes. Renúncia ao direito de indenização. Promessa de fato de terceiro. Estipulação em favor de terceiro. In:

Estudos e pareceres de direito privado. São Paulo: Saraiva, 2004, p. 198-207.

. Natureza jurídica do leasing financeiro. In: Estudos e pareceres de direito privado. São Paulo: Saraiva, 2004, p. 263-270.

. Contrato-quadro. Impossibilidade superveniente da obrigação de celebração dos contratos de execução (compra e venda) por inexistência de critério consensual para estipulação do preço. In: . Novos estudos e pareceres de direito privado. São Paulo: Saraiva, 2009, p. 162-181.

. A liberdade de contrato: contratos típicos e atípicos, Revista do Advogado, São Paulo, ano 2, n. 8, p. 10-17, jan./mar. 1982.

BALBI, Giovanni. La donazione. Milano: Francesco Vallardi, 1964. 
BARDET-BLANVILLAIN, Aurélie. L'échange. Tese (Doutorado em Direito Privado) Université Pantheon-Assas, Paris II, Paris, 2002.

BAUDELAIRE, Charles. Le spleen de Paris ou les cinquantes petits poèmes en prose de Charles Baudelaire. Paris: Émile-Paul, 1917.

BAUDRY-LACANTINERIE, Gabriel. Précis de droit civil. Paris: L. Larose et Forcel, 1883.

BDINE JUNIOR, Hamid Charaf. Comentário ao art. 304. In: PELUSO, Cezar (coord.). Código Civil comentado. 7. ed. rev. e atual. Barueri: Manole, 2013, p. 271-277.

BECKER, Anelise. Teoria geral da lesão nos contratos. São Paulo: Saraiva, 2000.

BÉNABENT, Alain. Droit des obligations. 16. ed. Issy-les-Moulineaux: LGDJ, 2017. . Droit des contrats spéciaux civils et commerciaux. Issy-les-Moulineaux: LGDJ, 2017. . L'hybridation dans les contrats. In: PROSPECTIVES du droit économique: dialogues avec Michel Jeantin. Paris: Dalloz, 1999.

BENTO XVI. Carta encíclica "Deus caritas est". Tradução oficial para o português. Roma: Santa Sé, 2005.

BERGSMAN, Bernard. Essai de systématisation nouvelle des contrats en droit privé. Revue de la Recherche Juridique, ano 15, n. 42, p. 411-451, jul./set. 1990.

BETTI, Emilio. Interpretação da lei e dos atos jurídicos. Tradução Karina Jannini. São Paulo: Martins Fontes, 2007.

. Teoria generale del negozio giuridico. 2. ed. Napoli: Edizioni Scientifiche Italiane, 2002.

BEVILAQUA, Clóvis. Código Civil dos Estados Unidos do Brasil comentado. 3. ed. Rio de Janeiro: Francisco Alves, 1927, v. 1. . Código Civil dos Estados Unidos do Brasil commentado. 6. ed. Rio de Janeiro: Francisco Alves, 1943, v. 4. 
BEVILAQUA, Clóvis. Código Civil dos Estados Unidos do Brasil. 6. ed. Rio de Janeiro: Francisco Alves, 1943, v. 6.

. Direito das obrigações. 5. ed. rev. Rio de Janeiro: Freitas Bastos, 1940.

BIANCA, Cesare Massimo. Diritto civile: il contratto. 2. ed. Milano: Giuffrè, 2000, v. 3. . La vendita e la permuta. 2. ed. Torino: UTET, 1993, t. 1.

BIONDI, Biondo. Le donazioni. Torino: UTET, 1961.

BISCONTINI, Guido. Onerosità, corrispettività e qualificazione dei contratti: il problema della donazione mista. Napoli: Edizione Scientifiche Italiane, 1984.

BONFANTE, Pietro. Diritto romano. Firenze: Fratelli Cammelli, 1900.

BONILINI, Giovanni. Manuale di diritto ereditario e delle donazioni. 5. ed. Torino: UTET, 2011.

BOUTHINON-DUMAS, Hughes. À la recherche d'un concept socio-économique de gratuité. In: MARTIAL-BRAZ, Nathalie; ZOLYNSKI, Celia (dir.). La gratuité: un concept aux frontières de l'économie et du droit. Paris: LGDJ, 2013, p. 15-37.

BOZZI, Lucia. Alla ricerca del contratto gratuito atipico. Rivista di diritto civile, Padova, CEDAM, v. 50, n. 2, parte 2, p. 209-224, mar./abr. 2004.

BRAGA, Carlos David Albuquerque. Contrato de franquia empresarial. In: PEREIRA JUNIOR, Antonio Jorge; JABUR, Gilberto Haddad. Direitos dos contratos II. São Paulo: Quartier Latin, 2008, p. 77-90.

BRASIL. Código Civil brasileiro: trabalhos relativos à sua elaboração. Rio de Janeiro: Imprensa Nacional, 1917, v. 1.

BROS, Sarah. L'interdépendance contractuelle, la Cour de Cassation et la réforme du droit des contrats. Recueil Dalloz, Paris, p. 29 e ss., 2016.

BUCKLER, William Hepburn. The origin and history of contract in roman law down to the end of the republican period. London: Cambridge University Press, 1895. 
BUENO, Francisco de Godoy. Regime jurídico dos contratos atípicos no direito brasileiro. Revista de Direito Civil Contemporâneo, São Paulo, v. 6, , p. 55-73, jan./mar. 2016.

BUFNOIR, Claude. Propriété et contrat: théories des modes d'acquisition des droits réels et de sources des obligations. Paris: Arthur Rousseau, 1900.

BUNAZAR, Mauricio Baptistella. Análise dogmática da categoria jurídica da invalidade no Código Civil brasileiro. Tese (Doutorado em Direito) - Faculdade de Direito da Universidade de São Paulo, São Paulo, 2017.

CAILlÉ, Alain. De l'idée de contrat. Le contrat comme don à l'envers (et réciproquement). In: JAMIN, Christophe; MAZEAUD, Denis. La nouvelle crise $d u$ contrat. Paris: Dalloz, 2003, p. 27-50.

CAMILO JUNIOR, Ruy Pereira. Contrato de distribuição ou concessão mercantil. In: PEREIRA JUNIOR, Antonio Jorge; JABUR, Gilberto Haddad (coord.). Direito dos contratos. São Paulo: Quartier Latin, 2006, p. 451-467.

CAMPOS, Diogo Leite de. Contrato a favor de terceiro. Coimbra: Almedina, 2009.

CAMPOS FILHO, Paulo Barbosa de. O problema da causa no direito civil brasileiro. São Paulo: Max Limonad, 1960.

CAPITANT, Henri. De la cause des obligations. Paris: Dalloz, 1927.

. Préface. In: REGNAULT, Henri. Les ordonnances civiles du Chancelier Daguesseau. Paris: Recueil Sirey, 1929, p. V-XIX.

CARBONNIER, Jean. Droit civil. 2. ed. Paris: PUF, 2017, v. 2.

. Flexible droit: pour une sociologie du droit sans rigueur. 10. ed. Paris: LGDJ, 2001.

Sociologie du contrat. In: Écrits. Textes rassemblés par Raymond Verdier. Paris: PUF, 2008, p. 587-593.

CARNELUTTI, Francesco. Teoria geral do direito. Tradução A. Rodrigues Queiró e Artur Ancelmo de Castro. Rio de Janeiro: Âmbito Cultural, 2006. 
CASTRO, Torquato. Da causa no contrato. Recife: Imprensa Universitária, 1966.

CATALA, Pierre. Interprétation et qualification dans l'avant-projet de réforme des obligations. In: Études offertes à Geneviève Viney. Paris: LGDJ, 2008, p. 243-257.

CATAUDELLA, Antonino. Sul contenuto del contratto. Milano: Giuffrè, 1966.

CHANIAL, Philippe. Renouer les fils de l'alliance. Bourgeois, Durkheim et l'incomplétude du contrat. In: JAMIN, Christophe; MAZEAUD, Denis. La nouvelle crise du contrat. Paris: Dalloz, 2003, p. 51-67.

CHANTEPIE, Gael; LATINA, Mathias. La réforme du droit des obligations: commentaire théorique et pratique dans l'ordre du Code Civil. Paris: Dalloz, 2016.

CHÉNEDÉ, François. Les commutations en droit privé: contribution à la théorie générale des obligations. Paris: Economica, 2008.

. De l'autonomie de la volonté à la justice commutative: du mythe à la réalité. Annuaire de l'Institut Michel Villey, v. 4, p. 155-181, 2012.

. Napoléon Bonaparte, lésion et violence. Revue des Contrats, Lextenso, Paris, n. 03 , p. 527 e ss., 01 set. 2014.

CÍCERO. On old age. Tradução Andrew P. Peabody. Boston: Little, Brown and Company, 1884.

. On oratory and orators. Tradução J. S. Watson. New York: Harper \& Brothers, 1875.

. Les Catilinaires et le dialogue sur les orateurs illustres de Cicéron. Tradução J. L. Burnouf. Paris: Brédif, 1826.

CICU, Antonio. La divisione ereditaria. Milano: Giuffrè, 1947.

COELHO, Fabio Ulhoa. Manual de direito comercial: direito de empresa. 23. ed. São Paulo: Saraiva, 2011.

COELHO, Francisco Manuel de Brito Pereira. O problema do regime dos contratos mistos: distinção entre as normas ou os problemas que tocam directamente a própria 
prestação e as normas ou os problemas que tocam o contrato na sua unidade. Boletim da Faculdade de Direito, Universidade de Coimbra, Coimbra, n. 88, p. 679-708, 2012.

COELHO DA ROCHA, Manuel António. Instituições de direito civil portuguez. Coimbra: Imprensa da Universidade, 1852, t. 1.

COHEN, Daniel. La bonne foi contractuelle: éclipse et renaissance. In: Le Code Civil: un passé, un présent, un avenir. Paris: Dalloz, 2004, p. 517-538.

COLIN, Ambroise; CAPITANT, Henri. Cours élémentaire de droit civil français. Paris: Dalloz, 1915, t. 2.

COMIRAN, Giovana Cunha. Atipicidade contratual: entre a autonomia privada e o tipo. Dissertação (Mestrado em Direito) - Faculdade de Direito, Universidade Federal do Rio Grande do Sul, Porto Alegre, 2007.

A exegese do art. 425 do Código Civil e o método tipológico: notas sobre critérios hermenêutico-integrativos dos contratos atípicos. In: MOTA, Mauricio; KLOH, Gustavo (Org.). Transformações contemporâneas do direito das obrigações. Rio de Janeiro: Elsevier, 2011, p. 597-638.

COMPARATO, Fábio Konder. Essai d'analyse dualiste de l'obligation en droit privé. Paris: Dalloz, 1964.

. Franquia e consessão de venda no Brasil: da consagração ao repúdio? Revista de Direito Mercantil, n. 18, p. 53-65, 1975.

COOTER, Robert; ULEN, Thomas. Law and economics. 6. ed. Boston: AddisonWesley, 2012.

CORREIA, Antonio Ferrer. Erro e interpretação na teoria do negócio jurídico. 4. reimp. Coimbra: Almedina, 2001.

COSTA, Mario Júlio de Almeida. Direito das obrigações. 7. ed. rev. e atual. Coimbra: Almedina, 1999.

COUTO E SILVA, Clóvis V. do. A obrigação como processo. Rio de Janeiro: Editora FGV, 2006. 
CRUZ, Emidio Pires da. Dos vícios redibitórios no direito português. Lisboa: Portugália, 1942.

D'AQUIN, Saint Thomas. La Somme théologique de Saint Thomas. Tradução Frade Drioux. Paris: Eugène Belin, 1855, t. 8.

DAWSON, John P. Gifts and promises: continental and american law compared. New Haven: Yale University Press, 1980.

DEL NERO, João Alberto Schützer. Conversão substancial do negócio jurídico. Rio de Janeiro: Renovar, 2001.

DEROUSSIN, David. Histoire du droit des obligations. Paris: Economica, 2007.

DESHAYES, Olivier. Gratuité et contrat: l'acte à titre gratuit est-il un contrat? In: MARTIAL-BRAZ, Nathalie; ZOLYNSKI, Celia (dir.). La gratuité: un concept aux frontières de l'économie et du droit. Paris: LGDJ, 2013, p. 133-149.

; GENICON, Thomas; LAITHIER, Yves-Marie. Réforme du droit des contrats, du régime général et de la preuve des obligations: commentaire article par article. Paris: Lexisnexis, 2016.

DERZI, Misabel de Abreu Machado. Tipo ou conceito no Direito Tributário? Revista da Faculdade de Direito da UFMG, Belo Horizonte, v. 31, p. 213-260, 1987/1988.

DESPOTOPOULOS, Constantin. La notion de synallagma chez Aristote. Archives de Philosophie du Droit, Paris, Sirey, n. 13, p. 115-127, 1968.

D'ETTORE, Felice Maurizio. Gratuità, liberalità e scambio. In: LIPARI, Nicolò; RESCIGNO, Pietro (dir.). Diritto civile: successioni, donazioni, beni. Le successioni e le donazioni. v. 2. t. 1. Milano: Giuffrè, 2009, p. 487-546.

DE VINCELLES, Carole Aubert. Réflexions sur les ensembles contractuels: un droit en devenir. Revue des Contrats, Lextenso, n. 3, p. 983 e ss., jul. 2007.

DISSAUX, Nicolas. Les mystères du contrat cadre. Actualité Juridique Contrat, Dalloz, Paris, p. 104 e ss., 2017. 
DOMAT, Jean. Les lois civiles dans leur ordre naturel. 2. ed. Paris: Pierre Auboüin, 1697, t. 1 .

DUARTE, Rui Pinto. Tipicidade e atipicidade dos contratos. Coimbra: Almedina, 2000.

DUPICHOT, Jacques. Pour un retour aux textes: défense et illustration du 'petit guideâne' des articles 1156 à 1164 du Code Civil. In: Études offertes à Jacques Flour. Paris: Defrénois, 1979, p. 179-206.

DUTILlEUL, François Collart; DELEBECQUE, Philippe. Contrats civils et commerciaux. 9. ed. Paris: Dalloz, 2011.

DWORKIN, Ronald. Law's empire. Cambridge, Harvard University Press, 1986.

ENNECCERUS, Ludwig; LEHMANN, Heinrich. Derecho de obligaciones. Tradução e comentários Blas Pérez Gonzalez e José Alguer. Barcelona: BOSCH, 1935, v. 2, t. 2.

FABRE-MAGNAN, Muriel. Droit des obligations: contrat et engagement unilatéral. 4. ed. Paris: PUF, 2016, v. 1.

. Droit des obligations: contrat et engagement unilatéral. 3. ed. Paris: PUF, 2007, v. 1 .

FARNSWORTH, Edward Allan. L'américanisation du droit: mythes ou réalités. Archives de Philosophie du Droit, Paris, v. 45, p. 21-28, 2001.

FACHIN, Luiz Edson; PIANOVSKI, Carlos Eduardo. Sucessão hereditária e colação: novo Código Civil e velhas polêmicas. Revista Brasileira de Direito Comparado, Rio de Janeiro, n. 30, p. 71-88, jan./jun. 2006.

FAUVARQUE-COSSON, Bénédicte. Les nouvelles règles du Code civil relatives à l'interprétation des contrats: perspective comparatiste et internationale. Revue des contrats, n. 02, p. 363 e ss., 01 jun. 2017.

FERRARA, Luigi Cariota. Il negozio giuridico nel diritto privato italiano. Napoli: Edizioni Scientifiche Italiane, 2011.

FERREIRA, Antonio Carlos. Revisão Judicial dos Contratos. In: BRASIL. Doutrina: edição comemorativa - 25 anos. Brasília: Superior Tribunal de Justiça, 2014, p. 395-407. 
FERREIRA, Nelson Pinto. Da colação no direito civil brasileiro e no direito civil comparado. São Paulo: Juarez de Oliveira, 2002.

FERRI, Giovanni B. Il negozio giuridico. 2. ed. Milano: CEDAM, 2004. Causa e tipo nella teoria del negozio giuridico. Milano: Giuffrè, 1963.

FIORI, Roberto. Il problema dell'oggetto del contratto nella tradizione civilistica. In: Modelli teorici e metodologici nella storia del diritto privato. Napoli: Jovene, 2003, p. $169-238$.

FORGIONI, Paula Andrea. Contrato de distribuição. 2. ed. São Paulo: Revista dos Tribunais, 2008.

FORTI, Valerio. L'absortion de l'objet par le contenu du contrat. Petites Affiches, Paris, n. 218 , p. 6 e ss., 31 out. 2014.

FLOUR, Jacques; AUBERT, Jean-Luc; SAVAUX, Éric. Les obligations: l'acte juridique. 16. ed. Paris: Sirey, 2014, v. 1.

FLUME, Werner. El negocio juridico. Tradução José María Miquel González e Esther Gómes Calle. Madrid: Fundación Cultural del Notariado, 1998.

FRADERA, Vera Jacob de. Contrato de distribuição. In: CARVALHOSA, Modesto (Coord.). Tratado de direito empresarial: contratos mercantis. 2. ed. São Paulo: Revista dos Tribunais, 2018, v. 4, p. 131-192.

FRANÇA, Rubens Limongi. Colação de bens doados. Revista dos Tribunais, São Paulo, ano 57, v. 516, p. 25-31, out. 1978.

FROMONT, Michel; KNETSCH, Jonas. Droit privé allemand. 2. ed. Issy-lesMoulineaux: LGDJ, 2017.

FUBINI, Riccardo. La teoria dei vizi redibitorii nel diritto civile e commerciale italiano. Torino: Fratelli Bocca Editori, 1906.

GABBA, Carlo Francesco. Della donazione larvata sotto forma di un contratto oneroso mancante delle formalità dell'atto pubblico. In: . Nuove questioni di diritto civile. v. 2. Torino: Fratelli Bocca, 1906, p. 81-97. 
GABRIELLI, Enrico. Tipo contrattuale. In: PARADISI, Bruno (dir.). Enciclopedia giuridica. vol. 35. Roma: Istituto della Enciclopedia Italiana, 2007.

. Storia e dogma dell'oggetto del contratto. Rivista di Diritto Civile, Padova, CEDAM, v. 50, n. 2, parte 1, p. 327-348, mar./abr. 2004.

GAGLIANO, Pablo Stolze. O contrato de doação: análise crítica do atual sistema jurídico e os seus efeitos no Direito de Família e das Sucessões. 4. ed. São Paulo: Saraiva, 2014.

GAIO. Instituições de direito privado romano. Tradução J. A. Segurado e Campos. Lisboa: Calouste Gulbenkian, 2010.

GALGANO, Francesco. Il negozio giuridico. Milano: Giuffrè, 2002.

GALLO, Paolo. Soppravvenienza contrattuale e problemi di gestione del contratto. Milano: Giuffrè, 1992.

GARCEZ, Martinho. Nullidades dos actos jurídicos. Rio de Janeiro: Cunha \& Irmão, 1896.

GARCÍA DEL CORRAL, Ildefonso L. Cuerpo de derecho civil romano: digesto. Barcelona: Jaime Molinas, 1892, v. 2. . Cuerpo de derecho civil romano: digesto. Barcelona: Jaime Molinas, 1897, v. 3. . Cuerpo de derecho civil romano: código. Barcelona: Jaime Molinas, 1892, v. 4.

GARRIGUES, Brigitte. La contre-prestation du franc symbolique. Revue Trimestrielle de Droit Civil, Paris, Dalloz, p. 459 e ss., 1991.

GATT, Lucilla. Onerosità e liberalità. Rivista di Diritto Civile, Padova, n. 49, p. 655$689,2003$. . La liberalità. Torino: G. Giappichelli, 2002, v. 1. . La liberalità. Torino: G. Giappichelli, 2012, v. 2. 
GAUTIER, Pierre-Yves. La cause du transfert de propriété, dans les ventes d'entreprises en difficulté. Revue Trimestrielle de Droit Civil, Paris, Dalloz, p. 124 e ss., 1994.

GENNARO, Gino de. I contratti misti: delimitazione, classificazione e disciplina. Negotia mixta cum donatione. Padova: CEDAM, 1934.

GHESTIN, Jacques. Cause de l'engagement et validité du contrat. Paris: LGDJ, 2006. ; JAMIN, Christophe; BILIAU, Marc. Traité de droit civil: effets du contrat. 3. ed. Paris: LGDJ, 2001.

GIORGI, Giorgio. Teoria delle obbligazioni nel diritto moderno italiano. v. 3. 2. ed. Firenze: Eugenio e Filippo Cammelli, 1885, v. 3.

GIRINO, Franco. Studi in tema di stipulazione a favore di terzi. Milano: Giuffrè, 1965. GODOY, Cláudio Luiz Bueno de. Função social do contrato: os novos princípios contratuais. 4. ed. São Paulo: Saraiva, 2012.

- Adimplemento e extinção das obrigações. Pagamento. Noção. Aspectos subjetivos. De quem deve pagar. Daqueles a quem se deve pagar. In: LOTUFO, Renan; NANNI, Giovanni Ettore (coord.). Obrigações. São Paulo: Atlas, 2011, p. 294-320.

GOMES, Orlando. Contratos. 26 ed. atual. por Antonio Junqueira de Azevedo e Francisco Paulo de Crescenzo Marino. Rio de Janeiro: Forense, 2007. . Introdução ao direito civil. 3. ed. Rio de Janeiro: Forense, 1971.

GOMIDE, Alexandre Junqueira. Contratos built to suit: aspectos controvertidos decorrentes de uma nova modalidade contratual. Dissertação (Mestrado) - Faculdade de Direito da Universidade de São Paulo, São Paulo, 2017.

GONZALEZ, Amparo. The possible motivation of the Lex Cincia de donis et numeribus. Revue Internationale des Droits de l'Antiquité, Paris, 3. série, v. 34, p. 161-171, 1987.

GORDLEY, James. Contract law in pre-commercial societies and in western history. In: MEHREN, Arthur von (ed.). International Encyclopedia of comparative law. Tübingen: J. B. Mohr, 1997, v. 7. cp. 2, p. 3-50. 
GORDLEY, James. The philosophical origins of modern contract doctrine. Oxford: Oxford University Press, 1992.

GORLA, Gino. I problemi fondamentali del contratto: princípi, metodi e tecniche del civil law in comparazione con il common law. Tradução Antonio Di Fede, Pietro Piccioni, Manuela Giobbi, Ettore William Di Mauro. Napoli: Edizioni Scientifiche Italiane, 2017.

. Contratto a favore di terzi e nudo patto. Rivista di Diritto Civile, Padova, ano 5, n. 1, p. 585-603, 1959.

GRILlET-PONTON, Dominique. Nouveau regard sur la vivacité de l'innommé en matière contractuelle. Recueil Dalloz, Paris, p. 331 e ss., 2000.

GRIMALDI, Cyril. La valeur normative des directives d'interprétation. Revue des contrats, n. 01, p. 154 e ss., 31 mar. 2015.

GRIMALDI, Michel. Droit civil: libéralités, partages d'ascendants. Paris: Litec, 2000.

GROSSI, Paolo. A ordem jurídica medieval. Tradução Denise Rossato Agostinetti. São Paulo: Martins Fontes, 2014.

GROTIUS, Hugues. Le droit de la guerre et de la paix. Tradução Jean Barbeyrac. Amsterdam: Pierre de Coup, 1724.

HAICAL, Gustavo. O contrato de agência: seus elementos tipificadores e efeitos jurídicos. São Paulo: Revista dos Tribunais, 2012.

HAMEL, Joseph. La notion de cause dans les libéralités. Paris: Sirey, 1920.

HATZIS, Aristides N. Having the cake and eating it too: efficient penalty clauses in Common and Civil contract law. International Review of Law and Economics, v. 22, p. 381-406, 2003.

HRANFKEL'S saga and other stories. Tradução por Hermann Pálsson. Suffolk: Penguin Books, 1970.

HERRERA, Marisa; CARAMELO, Gustavo; PICASSO, Sebastián (dir.). Código Civil y Comercial de la Nación comentado. Buenos Aires: Infojus, 2015, t. 3. 
HIRATA, Alessandro; TARTAGLIA, João Manoel Meneguesso. Built to suit: dos aspectos contratuais ao direito de superfície. Revista Brasileira de Direito Civil em Perspectiva, Salvador, v. 4, n. 1, p. 145-165, jan./jun. 2018.

HORBACH, Carlos Bastilde. A nova roupa do direito constitucional: neoconstitucionalismo, pós-positivismo e outros modismos. Revista dos Tribunais, São Paulo, v. 859, p. 81-91, mai. 2007.

HUC, Théophile. Commentaire théorique et pratique du Code Civil. Paris: Dalloz, 1894, t. 6 .

HULOT, Henri Marie Joseph. Les cinquantes livres du Digeste ou des Pandectes de l'empereur Justinien. Metz: Behmer et Lamort, 1804, t. 2.

. Les cinquantes livres du Digeste ou des Pandectes de l'empereur Justinien. Metz: Behmer et Lamort, 1804, t. 3.

. Les cinquantes livres du Digeste ou des Pandectes de l'empereur Justinien. Metz: Behmer et Lamort, 1804, t. 6.

HYLAND, Richard. Gifts: a study in comparative law. Oxford: Oxford University Press, 2009.

ITÁlIA. Codice Civile del Regno d'Italia. Torino: Stamperia Reale, 1865.

JAMIN, Christophe. Plaidoyer pour le solidarisme contractuel. In: Études offertes à Jacques Ghestin: le contrat au début du XXIe siècle. Paris: LGDJ, 2001, p. 441-472.

JACQUES, Philippe. Regards sur l'article 1135 du Code civil. Paris: Dalloz, 2005.

JOSSERAND, Louis. Les mobiles dans les actes juridiques de droit privé. Paris: Dalloz, 2006.

. L'essor moderne du concept contractuel. In: Recueil d'études sur les sources du droit en l'honneur de François Gény. t. 2. Paris: Recueil Sirey, 1934, p. 333-346.

KASER, Max. Direito privado romano. Lisboa: Calouste Gulbenkian, 1999.

KASIRER, Nicholas. Agapè. Revue Internationale de Droit Comparé, Paris, v. 53, n. 3, p. 575-600, jul./set. 2001. 
KHOURI, Paulo R. Roque A. A revisão judicial dos contratos no novo Código Civil, Código do Consumidor e Lei $n^{\circ}$ 8.666/93: a onerosidade excessiva superveniente. São Paulo: Atlas, 2006.

KONDER, Carlos Nelson. Causa e tipo: a qualificação dos contratos sob a perspectiva civil-constitucional. Rio de Janeiro: s. e. c., 2014.

. Para além da 'principialização' da função social do contrato. Revista Brasileira de Direito Civil, Belo Horizonte, v. 13, p. 39-59, jul./set. 2017.

. Qualificação e coligação contratual. Revista Forense, Rio de Janeiro, ano 105, v. 406, p. 55-86, nov./dez. 2009.

KÖTZ, Hein. European contract law. 2. ed. Tradução Gill Mertens e Tony Weir. Oxford: Oxford University Press, 2017.

LABARTHE, Françoise. Les conflits de qualification. In: Les droits et le Droit: mélanges dédiés à Bernard Bouloc. Paris: Dalloz, 2007.

. La fixation unilatérale du prix dans les contrats cadre et prestations de service. La Semaine Juridique, Lexisnexis, p. 1110 e ss., jun. 2016.

LAGARDE, Xavier. Réflexions sur le fondement de l'article 931 du code civil. Revue Trimestrielle de Droit Civil, Paris, Dalloz, n. 1, p. 25 e ss., 14 mar. 1997.

LARENZ, Karl. Metologia da ciência do direito. 3. ed. Tradução José Lamego. Lisboa: Calouste Gulbenkian, 1997.

Derecho civil: parte general. Tradução Miguel Izquierdo e Macías-Picavea. Madrid: EDERSA, 1978.

. Derecho de obligaciones. Tradução Jaime Santos Briz. Madrid: EDERSA, 1959, t. 2.

LAROMBIÈRE, Léobon Valéry Léon Jupile. Théorie et pratique des obligations. Paris: A. Durand et Pedone-Lauriel, 1885, t. 1.

LARROUMET, Christian; BROS, Sarah. Traité de droit civil: les obligations, le contrat. 8. ed. Paris: Economica, 2016, t. 3. 
LARROUMET, Christian; MONDOLONI, Dominique. Stipulation pour autrui. In: Répertoire de droit civil. Paris: Dalloz, 2017.

LÉCUYER, Hervé. Le contrat, acte de prévision. In: L'avenir du droit: mélanges en hommage à François Terré. Paris, Dalloz, 1999, p. 644-645.

LEITÃO, Luís Manuel Teles de. Direito das obrigações: contratos em especial. 6. ed. Coimbra: Almedina, 2009, v. 3.

LEITE, Eduardo de Oliveira. Comentários ao novo Código Civil: do direito das sucessões. 5. ed. Rio de Janeiro: Forense, 2009, v. 21.

LENER, Giorgio. Profili del collegamento negoziale. Milano: Giuffrè, 1999.

LEONARDO, Rodrigo Xavier. Redes contratuais no mercado habitacional. São Paulo: Revista dos Tribunais, 2003.

. Os contratos coligados, os contratos conexos e as redes contratuais. In: CARVALHOSA, Modesto (coord.). Tratado de direito empresarial. São Paulo: Revista dos Tribunais, 2016, v. 4, p. 459-496.

. O contrato built to suit. In: CARVALHOSA, Modesto (Coord.). Tratado de direito empresarial: contratos mercantis. 2. ed. São Paulo: Revista dos Tribunais, 2018, v. 4, p. $453-488$.

A cessão de créditos à luz da tese da separação relativa. In: MARTINS-

COSTA, Judith; FRADERA, Véra Jacob de (org.). Estudos de direito privado e processual civil: em homenagem a Clóvis do Couto e Silva. São Paulo: Revista dos Tribunais, 2014, p. 255-277.

. O pensamento tipológico e os tipos contratuais gerais. Revista de Direito Civil Contemporâneo, São Paulo, v. 16, ano 5, p. 121-135, jul./set. 2018.

A denúncia e a resilição: críticas e propostas hermenêuticas ao art. 473 do CC/2002 brasileiro. Revista de Direito Civil Contemporâneo, ano 3, v. 7, p. 95-117, abr./jun. 2016.

LEQUETTE, Yves. Bilan des solidarismes contractuels. In: Mélanges offertes à Paul Didier: études de droit privé. Paris: Economica, 2006, p. 247-287. 
LIMA, Fernando Andrade Pires de. ANTUNES VARELA, João de Matos. Código Civil anotado. 2. ed. rev. e actual. Coimbra: Coimbra Editora, 1987, v. 2.

LOBÃO, Manoel d'Almeida e Sousa de. Notas a Mello. Lisboa: Impressão Régia, 1818, v. 2.

LÔBO, Paulo Luiz Netto. Direito civil: parte geral. 4. ed. São Paulo: Saraiva, 2013. . Direito civil: contratos. São Paulo: Saraiva, 2011. . Comentários ao Código Civil. São Paulo: Saraiva, 2003, v. 6.

LOKIEC, Pascal. Le droit des contrats et la protection des attentes. Recueil Dalloz, Paris, p. 321 e ss., 2007.

LORENZETTI, Ricardo Luis. Tratado de los contratos. Buenos Aires: RubinzalCulzoni, 1999, t. 1.

LUCAS-PUGET, Anne-Sophie. Essai sur la notion d'objet du contrat. Paris: LGDJ, 2005.

MALAURIE, Philippe; AYNÈS, Laurent; STOFFEL-MUNCK, Philippe. Droit des obligations. 8. ed. Issy-les-Moulineaux: LGDJ, 2016.

; BRENNER, Claude. Droit des successions et de libéralités. 7. ed. Issy-lesMoulineaux: LGDJ, 2016.

MALINVAUD, Philippe. Le « contenu certain » du contrat dans l'avant-projet « chancellerie » de code des obligations ou le «stoemp » bruxellois aux légumes. Recueil Dalloz, Paris, p. 2551 e ss., 2008.

MAMEDE, Gladston. Direito empresarial brasileiro: empresa e atuação empresarial. v. 1. São Paulo: Atlas, 2010.

MARINO, Francisco Paulo de Crescenzo. Contratos coligados no direito brasileiro. São Paulo: Saraiva, 2009. . Interpretação do negócio jurídico. São Paulo: Saraiva, 2011. 
MARINO, Francisco Paulo de Crescenzo. Classificação dos contratos. In: PEREIRA JUNIOR, Antonio Jorge; JABUR, Gilberto Haddad. Direitos dos contratos. São Paulo: Quartier Latin, 2006, p. 21-50.

MARKESINIS, Sir Basil; UNBERATH, Hannes; JOHNSTON, Angus. The german law of contract: a comparative treatise. 2. ed. Oxford: Hart Publishing, 2006.

MARTINS, Fran. Contratos e obrigações comerciais. 18. ed. rev., atual. e ampl. por Gustavo Saad Diniz. Rio de Janeiro: Forense, 2018.

MARTINS-COSTA, Judith. A boa-fé no direito privado: critérios para a sua aplicação. São Paulo: Marcial Pons, 2015.

- Comentários ao novo Código Civil: do direito das obrigações; do adimplemento e da extinção das obrigações. Rio de Janeiro: Forense, 2003, v. 5. t. 1.

. Como harmonizar os modelos jurídicos abertos com a segurança jurídica dos contratos?. Revista Jurídica Luso Brasileira, Lisboa, ano 2, jan./mar. 2016, n. 1, p. 10511064.

MASSON, Alexandre. Coutume de Paris mise en un nouvel ordre. Paris: Nicolas Gosselin, 1703.

MAURY, Jacques. Essai sur le rôle de la notion d'équivalence en droit civil français. Paris: Jouve \& Cie., 1920, t. 1.

MAUSS, Marcel. Essai sur le don: forme et raison de l'échange dans les sociétés archaïques. Paris: PUF, 2012.

MAXIMILIANO, Carlos. Direito das sucessões. Rio de Janeiro: Freitas Bastos, 1958, v. 3.

MAYER, Danièle. L'amitié. La Semaine Juridique, Paris, 1974, v. 47, t. I, n. 2663-2664.

MAZEAUD, Denis. Loyauté, solidarité, fraternité: la nouvelle devise contractuelle? In: L'Avenir du droit: mélanges en hommage à François Terré. Paris: Dalloz, 1999, p. 603634. 
MELLO, Marcos Bernardes de. Teoria do fato jurídico: plano da validade. 8. ed., rev. e atual. São Paulo: Saraiva, 2008.

MENEZES CORDEIRO, António. Tratado de direito civil. Coimbra: Almedina, 2012, v. 6.

MERGEY, Anthony. La gratuité à travers les frontières du temps. Quelques jalons. In: MARTIAL-BRAZ, Nathalie; ZOLYNSKI, Celia (dir.). La gratuité: un concept aux frontières de l'économie et du droit. Paris: LGDJ, 2013, p. 42-53.

MESSINEO, Francesco. Manuale di diritto civile e commerciale. 6. ed. riv. e amp. Padova: CEDAM, 1943, v. 3.

MICHEL, Jacques. Gratuité en droit romain. Bruxelles: Université Libre de Bruxelles, 1962.

MILLER, William I. Is a gift forever?. Representations, University of California Press, v. 100, n. 1, p. 13-22, set./nov. 2007.

MIRANDA, Custódio da Piedade Ubaldino. Comentários ao Código Civil. São Paulo: Saraiva, 2013, v. 5.

. Interpretação e integração dos negócios jurídicos. São Paulo: Revista dos Tribunais, 1989.

MOMMSEN, Theodor; KRÜGER, Paul. Corpus iuris civilis. 15. ed. Berlin: Weidmann, 1928, v. 1.

MONNIER, H. La Novelle $\mathrm{L}$ de Léon le Sage et l'insinuation des donations. In: Mélanges P. F. Girard. v. 2. Paris: Arthur Rousseau, 1912, p. 237-289.

MONTEIRO, Washington de Barros. Curso de direito civil. 30 ed. atual. São Paulo: Saraiva, 1991, v. 1.

MONTREDON, Jean-François. La désolennisation des libéralités. Paris: LGDJ, 1989.

MORAES, Bernardo B. Queiroz de. Manual de introdução ao Digesto. São Paulo: YK, 2017. 
MORAES, Maria Celina Bodin de. A causa do contrato. Civilística.com, Rio de Janeiro, v. 2, n. 1, p. 1-24, abr./jun. 2013.

. Notas sobre a promessa de doação. Cilivistica.com, Rio de Janeiro, v. 2, n. 3, p. 1-19, jul./set. 2013.

MORATO, Francisco. Da colação. Revista de Direito Privado, São Paulo, ano 1, v. 3, p. 215-222, jul./set. 2000.

MOREIRA ALVES, José Carlos. Direito romano. 15. ed. Rio de Janeiro: Forense, 2012. MORENO, Antonio Manuel Morales. El alcance protector de las acciones edilicias. Anuario de Derecho Civil, Madrid, fasc. 3, p. 585-686, 1980.

MOZOS, Jorge Luis de los. La colación. Madrid: REUS, 1965.

MOURY, Jacques. La fixation unilatérale du prix dans le contrat cadre. Actualité Juridique Contrats d'affaires, Dalloz, p. 123 e ss., 2016.

NAJJAR, Ibrahim. La notion $\mathrm{d}^{\prime}<<$ ensemble contractuel $>>$. In: Une certaine idée $d u$ contrat: mélanges à André Decocq. Paris: Litec, 2004, p. 509-525.

. Prix « sous-évalué » et intention libérale. Recueil Dalloz, Paris, Dalloz, p. 2591 e ss., 2003.

NERY JUNIOR, Nelson; PENTEADO, Luciano de Camargo. Doação pura, preliminar de doação e contratos de gestão. Revista de Direito Privado, São Paulo, ano 7, n. 25, p. 7-58, jan./mar. 2006.

NICOD, Marc. Le formalisme en droit des libéralités. La Baule: La Mouette, 2000.

NOVA, Giorgio de. Il tipo contrattuale. Padova: CEDAM, 1974.

OLIVEIRA, Euclides Benedito de. Colação e sonegados. In: HIRONAKA, Giselda Maria Fernandes Novaes; PEREIRA, Rodrigo da Cunha (coord.). Direito das sucessões. 2. ed. atual. Belo Horizonte: Del Rey, 2007, p. 381-398.

OPPO, Giorgio. Adempimento e liberalità. Milano: Giuffrè, 1947. 
OVERSTAKE, Jean-François. Essai de classification des contrats spéciaux. Paris: LGDJ, 1969.

PACIFICI-MAZZONI, Emidio. Istituzioni di diritto civile italiano. 2. ed. Firenze: Eugenio e Filippo Cammelli, 1872, v. 3.

. Istituzioni di diritto civile italiano. 2. ed. Firenze: Eugenio e Filippo Cammelli, 1873 , v. 5.

PAPALEO, João Cesar Guaspari. Contrato a favor de terceiro. Rio de Janeiro: Renovar, 2000.

PARGENDLER, Mariana. Desenho contratual em perspectiva comparada: reflexões sobre a relação entre tipificação legal e inovação contratual. Revista da Faculdade de Direito - UFPR, Curitiba, v. 61, n. 1, p. 219-245, jan./abr. 2016.

PAUL, François. Les choses qui sont dans le commerce au sens de l'article 1128 du Code Civil. Paris: LGDJ, 2002.

PENTEADO, Luciano de Camargo. Redes contratuais e contratos coligados. In: HIRONAKA, Giselda M. F. N.; TARTUCE, Flávio (coords.). Direito contratual: temas atuais. São Paulo: Método, 2007, p. 463-492.

. Contratos eficazes perante terceiros. Revista do Advogado, São Paulo, ano 32, n. 116, p. 119-131, jul. 2012.

. Doação com encargo e causa contratual. 2. ed. rev., atual. e ampl. São Paulo: Revista dos Tribunais, 2013.

. Direito das coisas. 2. ed. rev., atual. e ampl. São Paulo: RT, 2012.

- Efeitos contratuais perante terceiros. Tese (Doutorado em Direito) Faculdade de Direito da Universidade de São Paulo, São Paulo, 2006.

. Integração de contratos incompletos. Tese (Livre-Docência) - Faculdade de Direito de Ribeirão Preto, Universidade de São Paulo, Ribeirão Preto, 2013.

PEREIRA, Caio Mário da Silva. Obrigações e contratos: pareceres de acordo com o Código Civil de 2002. Seleção, atualização e ementas por Leonardo de Campos Melo, Ricardo Loretti Henrici e Cristiane da Silva Pereira Motta. Rio de Janeiro: Forense, 2011. 
PEREIRA, Caio Mário da Silva. Instituições de direito civil. 23. ed. rev. e atual. por Maria Celina Bodin de Moraes. Rio de Janeiro: Forense, 2009, v. 1.

. Instituições de direito civil. 24. ed. rev. e atual. por Maria Celina Bodin de Moraes. Rio de Janeiro: Forense, 2011, v. 1.

. Instituições de direito civil: teoria geral das obrigações. 24. ed. atual. por Guilherme Calmon Nogueira da Gama. Rio de Janeiro: Forense, 2011, v. 2.

. Instituições de direito civil: contratos. 16. ed. rev. e atual. por Regis Fichtner. Rio de Janeiro: Forense, 2012, v. 3.

. A lesão nos contratos. 6. ed. Rio de Janeiro: Forense, 1997.

PEREIRA, Rodrigo Serra. Do planejamento sucessório: uma breve análise da doação de ascendente para descendente. Revista de Direito Civil Contemporâneo, São Paulo, v. 13, ano 4, p. 349-371, out./dez. 2017.

PINTO, Carlos Alberto da Mota. Forma, interpretação e integração negocial. Revista de direito comparado luso-brasileiro, Rio de Janeiro, jul. 1982, n. 1, p. 60-76.

PLANIOL, Marcel. Classification synthétique des contrats. Revue critique de législation et de jurisprudence, Paris, LGDJ, v. 53, t. 33, p. 470-490, 1904.

. Traité élémentaire de droit civil. 2. ed. Paris: Dalloz, 1902, t. 2.

POLLAUD-DULIAN, Frédéric. Le contrat-cadre, par-delà les paradoxes. Revue Trimestrielle du Droit Commercial, Dalloz, Paris, p. 179 e ss., 1996.

PONTES DE MIDANDA, Francisco Cavalcanti. Tratado de direito privado. Atualizado por Judith Martins-Costa, Gustavo Haical e Jorge Cesa Ferreira da Silva. São Paulo: Revista dos Tribunais, 2012, t. 1.

. Tratado de direito privado. 3. ed. Rio de Janeiro: Borsoi, 1970, t. 1.

. Tratado de direito privado. Atualizado por Marcos Bernardes de Mello e Marcos Ehrhardt Jr. São Paulo: Revista dos Tribunais, 2012, t. 3. 
PONTES DE MIRANDA, Francisco Cavalcanti. Tratado de direito privado. Atualizado por Marcos Bernardes de Mello e Marcos Ehrhardt Jr. São Paulo: Revista dos Tribunais, 2012 , t. 4.

. Tratado de direito privado. 3. ed. Rio de Janeiro: Borsoi, 1970, t. 5.

. Tratado de direito privado. Atualizado por Nelson Nery Jr. e Rosa Maria de Andrade Nery. São Paulo: Revista dos Tribunais, 2012, t. 24.

. Tratado de direito privado. Rio de Janeiro: Borsoi, 1959, t. 26.

. Tratado de direito privado. Atualizado por Claudia Lima Marques e Bruno Miragem. São Paulo: Revista dos Tribunais, 2012, t. 38.

. Tratado de direito privado. 3. ed. Rio de Janeiro: Borsoi, 1972, t. 46.

. Tratado de direito privado. Atualizado por Bruno Miragem. São Paulo: Revista dos Tribunais, 2012, t. 46.

. Tratado de direito privado. 3. ed. Rio de Janeiro: Borsoi, 1972, t. 55.

. Tratado de direito privado. Atualizado por Giselda Hironaka e Paulo Lôbo. São Paulo: Revista dos Tribunais, 2012, t. 55.

PORTUGAL. Código Philippino ou Ordenações e leis do Reino de Portugal recompiladas por mandado d'El-Rey D. Philippe I. Anotações de Cândido Mendes de Almeida. 14. ed. Rio de Janeiro: Typographia do Instituto Philomathico, 1870.

- Ordenaçoens do Senhor Rey D. Affonso V. Coimbra: Real Imprensa da Universidade, 1786, v. 4.

POSNER, Richard. What do judges and justices maximize? (the same things everyone else does). Chicago Working Paper in Law and Economics, n. 15, p. 1-26, 1993.

POTHIER, Robert Joseph. Traité des obligations. Paris: Debure, 1764, t. 1.

. Traité des donations entre-vifs. In: . Oeuvres de Pothier contenant les traités de droit français. Paris: Bechet Ainé, 1825, t. 7.

PRINGSHEIM, Fritz. Animus in Roman Law II. Law Quarterly Review, v. 49, n. 195, p. 379-412, jul./set. 1933 . 
RABEL, E. L'origine de la règle impossibilium nulla obligatio. In: Mélanges Gérardin. Paris: Sirey, 1907, p. 473-512.

RAMIREZ, Paulo Nuno Horta Correia. O cônjuge sobrevivo e o instituto da colação. Coimbra: Almedina, 1997.

RAWACH, Eid. La portée des clauses tendant à exclure le rôle des documents précontractuels dans l'interprétation du contrat. Recueil Dalloz, Paris, p. 223 et ss., 2001.

REALE, Miguel. O direito como experiência. 2. ed. fac.-sim. São Paulo: Saraiva, 1992. REGNAULT, Henri. Les ordonnances civiles du Chancelier Daguesseau. Paris: Recueil Sirey, 1929.

RIBAS, Antonio Joaquim. Curso de direito civil brasileiro. Brasília: Senado Federal, 2003, v. 2.

RICARD, Jean-Marie. Traité des donations entre-vifs et testamentaires. Paris: Claude Robustel, 1734, t. 1.

RIEG, Alfred. Le rôle de la volonté dans l'acte juridique en droit civil français et allemand. Paris: LGDJ, 1961.

. Le rôle de la volonté dans la formation de l'acte juridique d'après les doctrines allemandes du XIXe siècle. Archives de Philosophie du Droit, t. 3, Paris, Sirey, p. 125133, 1957.

. Les contrats dans les doctrines allemandes du XIXe siècle. Archives de Philosophie du Droit, Paris, Sirey, t. 13, p. 31-49, 1968.

RIPERT, Georges; BOULANGER, Jean. Traité de droit civil. Paris: LGDJ, 1956, t. 2.

RIZZARDO, Arnaldo. Contratos. 17. ed. rev. e atual. Rio de Janeiro: Forense, 2018.

ROCHFELD, Judith. Cause et type de contrat. Paris: LGDJ, 1999.

RODRIGUES, Antônio Coelho. Projecto do Código Civil brazileiro. Rio de Janeiro: Imprensa Nacional, 1893. 
RODRIGUES, Dárcio Roberto Martins. Verba e voluntas no direito romano e no Código Civil brasileiro. Revista da Faculdade de Direito de São Bernardo do Campo, n. 11, p. 85-96, 2005.

RODRIGUES, Silvio. Direito civil. 32. ed. São Paulo: Saraiva, 2002, v. 1.

. Direito civil: parte geral. 34. ed. São Paulo: Saraiva, 2003, v. 1.

RODRIGUES JUNIOR, Otavio Luiz. Direito civil contemporâneo: estatuto epistemológico, Constituição e direitos fundamentais. Rio de Janeiro: Forense Universitária, 2018.

. Natureza, função e modificação da cláusula penal no direito civil brasileiro. Tese (Doutorado em Direito) - Faculdade de Direito da Universidade de São Paulo, São Paulo, 2006.

. Revisão judicial dos contratos: autonomia da vontade e teoria da imprevisão. 2. ed. rev., atual. e ampl. São Paulo: Atlas, 2006.

. Código Civil comentado: compra e venda, troca, contrato estimatório. São Paulo: Atlas, 2008, v. 6, t. 1.

- Um 'modelo de revisão contratual por camadas' e a jurisprudência contemporânea do Superior Tribunal de Justiça. In: LOPEZ, Teresa Ancona; LEMOS, Patrícia Faga Iglecias; RODRIGUES JUNIOR, Otavio Luiz (Coord.). Sociedade de risco e direito privado: desafios normativos, consumeristas e ambientais. São Paulo: Atlas, 2013, p. 469-514.

. A compra e venda mercantil. In: CARVALHOSA, Modesto (Coord.). Tratado de direito empresarial: contratos mercantis. 2. ed. São Paulo: Revista dos Tribunais, 2018, v. 4, p. 79-128.

- Análise comparativista dos contratos built to suit. Consultor Jurídico, 10.04.2013, disponível em: < https://www.conjur.com.br/2013-abr-10/direitocomparado-analise-comparativista-contratos-built-to-suit>, acesso em: 13 set. 2018.

- Propriedade e função social: exame crítico de um caso de 'constitucionalização' do direito civil. In: Estudos de homenagem ao Professor Doutor 
Jorge Miranda: direito constitucional e justiça constitucional. Coimbra: Coimbra Editora, 2012, v. 3, p. 61-89.

RODRIGUES JUNIOR, Otavio Luiz. A doutrina do terceiro cúmplice: autonomia da vontade, o princípio res inter alios acta, função social do contrato e a interferência alheia na execução dos negócios jurídicos. Revista dos Tribunais, São Paulo, ano 93, v. 821, p. 80-98, mar. 2004.

ROISIN, Christopher Alexander. Vicios redibitórios. São Paulo: YK, 2018.

ROPPO, Vincenzo. Diritto privato. Torino: Giappichelli, 2010.

Il contrato. 2. ed. Milano: Giuffrè, 2011.

. O contrato. Tradução Ana Coimbra e M. Januário C. Gomes. Coimbra: Almedina, 2009.

ROUHETTE, Georges. La doctrine de l'acte juridique: sur quelques matériaux récents. Revue Droits, Paris, n. 2, v. 7, p. 29-35, 1985.

. Contribution à l'étude critique de la notion de contrat. Tese (Doutorado em Direito) - Université de Paris, Paris, 1965.

RUBINO, Domenico. Il negozio giuridico indiretto. Milano: Giuffrè, 1937. . La compravendita. Milano: Giuffrè, 1952.

RUGGIERO, Roberto de. Instituciones de derecho civil. Tradução Ramón Serrano Suñer e José Santa-Cruz Teijeiro. Madrid: Reus, 1931, v. 2.

SACCO, Rodolfo. Autonomia contrattuale e tipi. Rivista Trimestrale di Diritto e Procedura Civile, Milano, n. 3, p. 785-808, jul./set. 1966.

; NOVA, Giorgio de. Il contratto. 4. ed. Torino: UTET, 2016.

SAINTE-MARIE, Anne Etienney de. Les principes, les directives et les clauses relatives à l'interprétation. Revue des contrats, n. 02, p. 384 e ss., 01 jun. 2016.

SAINTE-MARIE, Anne Etienney de. Gratuité et contrat: le régime du contrat à titre gratuit est-il un régime? In: MARTIAL-BRAZ, Nathalie; ZOLYNSKI, Celia (dir.). La 
gratuité: un concept aux frontières de l'économie et du droit. Paris: LGDJ, 2013, p. 151164.

SALEILLES, Raymond. Étude sur la théorie générale de l'obligation d'après le premier projet de Code Civil pour l'Empire Allemand. 3. ed. Paris: LGDJ, 1914.

SANSEVERINO, Paulo de Tarso. Contratos nominados II. 2. ed. rev., atual. e ampl. São Paulo: Revista dos Tribunais, 2011.

SANTOS, Joaquim Felício dos. Projecto do Código Civil brazileiro e commentário. Rio de Janeiro: Laemmert, 1887, t. 5.

SAVATIER, René. Observations sur les modes contemporains de formation du droit positif. In: Mélanges en l'honneur de Jean Dabin. v. 1. Paris: Sirey, 1963, p. 293-315.

SAVIGNY, Friedrich Karl von. Traité de droit romain. 2. ed. Tradução Ch. Genoux. Paris: Firmin Didot Frères, 1856, t. 3.

. Traité de droit romain. 2. ed. Tradução Ch. Genoux. Paris: Firmin Didot Frères, 1856, t. 4.

SBORDONE, Francesco. La donazione mista come negozio giuridico indiretto. In: PERLINGIERI, Pietro; POLIDORI, Stefano (org.). Domenico Rubino: interesse e rapporti giuridici. Napoli: Edizioni Scientifiche Italiane, 2009, p. 829-848.

SCHIZZEROTTO, Giovanni. Il collegamento negoziale. Napoli: Jovene Editore, 1983.

SCHREIBER, Anderson. Manual de direito civil contemporâneo. São Paulo: Saraiva, 2018.

SCUTO, Carmelo. Il modus nel diritto civile italiano. Palermo: Orazio Fiorenza, 1909.

SILVA, Jorge Cesa Ferreira da. A boa-fé e a violação positiva do contrato. Rio de Janeiro: Renovar, 2007. . Adimplemento e extinção das obrigações: comentários aos arts. 304 a 388 do Código Civil. São Paulo: Revista dos Tribunais, 2006.

SILVA, Virgilio Afonso da. A constitucionalização do direito: os direitos fundamentais nas relações entre particulares. São Paulo: Malheiros, 2011. 
SIMÃO, José Fernando. Vícios do produto no novo Código Civil e no Código de Defesa do Consumidor. São Paulo: Atlas, 2003.

. Venda de ascendentes a descendentes: razão de ser da regra. Revista de Direito Civil Contemporâneo, v. 1, ano 1, São Paulo, p. 103-112, out./dez. 2014.

. Natureza jurídica do dízimo e da doação: aparente semelhança, mas grandes e insuperáveis diferenças. Revista do Instituto do Direito Brasileiro, Lisboa, ano 2, n. 9, p. 10357-10386, 2013.

SIMLER, Philippe. Interprétation des contrats. Jurisclasseur Civil, fasc. 10, à jour au 12 juillet $2017, \mathrm{n}^{\circ} 5$.

SIMÕES, Marcel Edvar. Transmissão em direito das obrigações: cessão de crédito, assunção de dívida e sub-rogação pessoal. Dissertação (Mestrado em Direito) Faculdade de Direito da Universidade de São Paulo, São Paulo, 2011.

SOUZA, Sylvio Capanema de. Comentários ao novo Código Civil. Rio de Janeiro: Forense, 2004, v. 8.

SZTAJN, Rachel; GORGA, Érica. Tradições do Direito. In: ZYLBERSZTAJN, Decio; SZTAJN, Rachel (Org.). Direito e economia: análise econômica do direito e das organizações. Rio de Janeiro: Elsevier, 2005, p. 137-196.

STANICIA, Sergio Tuthill. Liberalidade e gratuidade no âmbito da doação. Tese (Doutorado em Direito) - Faculdade de Direito da Universidade de São Paulo, São Paulo, 2016.

. A liberalidade ou animus donandi como elemento caracterizador da doação. Revista de Direito Civil Contemporâneo, São Paulo, v. 13, n. 4, p. 99-138, out./dez. 2017. STOLLEIS, Michael; MACHADO, Gustavo Castagna (trad.). Interpretação judicial na transição do Antigo Regime ao constitucionalismo. Cadernos do Programa de PósGraduação em Direito, UFRGS, Porto Alegre, v. 9, n. 2, p. 13-39, 2014.

TEIXEIRA DE FREITAS, Augusto. Código Civil: esboço. Rio de Janeiro: Ministério da Justiça e Negócios Interiores, 1952, v. 2. 
TELLES, José Homem Corrêa. Digesto portuguez ou tratado dos modos de adquirir a propriedade, de a gozar e administrar, e de a transferir por derradeira vontade. Pernambuco: M. F. de Faria, 1839, v. 3.

TEPEDINO, Gustavo; BARBOZA, Heloisa Helena; MORAES, Maria Celina Bodin de (coord.). Código Civil interpretado. 2. ed. rev. e atual. Rio de Janeiro: Renovar, 2007, v. 1. ; ___ Código Civil interpretado conforme a Constituição da República. 2. ed. rev. e atual. Rio de Janeiro: Renovar, 2012, v. 2.. ; . Código Civil interpretado conforme a Constituição da República. Rio de Janeiro: Renovar, 2014, v. 4.

TEPEDINO, Gustavo. Os novos contratos no novo Código Civil. Revista da EMERJ, Rio de Janeiro, Edição especial, Parte I, p. 179-193, fev./jun. 2002.

TERRÉ, François. Le rôle de la volonté individuelle sur les qualifications. Paris: LGDJ, 1957.

. Volonté et qualification. Archives de Philosophie du Droit, Paris, Sirey, t. 3, p. 99-123, 1957.

; SIMLER, Philippe; LEQUETTE, Yves. Droit civil: les obligations. 11. ed. Paris: Dalloz, 2013.

et al. Droit civil: les obligations. 12. ed. Paris: Dalloz, 2018.

; LEQUETTE, Yves; GAUDEMET, Sophie. Droit civil: les successions, les libéralités. Paris: Dalloz, 2013.

THEODORO JÚNIOR, Humberto. Comentários ao novo Código Civil: dos defeitos do negócio jurídico ao final do Livro III. Rio de Janeiro: Forense, 2003, v. 3, t. 1.

TISSOT, Pascal-Alexandre. Les douzes livres du Code de l'Empereur Justinien. Metz: Behmer, 1807, t. 2.

TOMASETTI JUNIOR, Alcides. Abuso de poder econômico e abuso de poder contratual. Revista dos Tribunais, n. 84, v. 715, p. 87-107, mai. 1995. 
TOMASEVICIUS FILHO, Eduardo. Uma década de aplicação da função social do contrato: análise da doutrina e da jurisprudência brasileiras. Revista dos Tribunais, São Paulo, v. 940, p. 49 e ss., fev. 2014.

TORRENTE, Andrea. La donazione. 2. ed. atual. por Ugo Carnevali e Andrea Mora. Milano: Giuffrè, 2006.

VALIM, Thalles Ricardo Alciati. Contratos entre ascendentes e descendentes: regras de proteção aos quinhões legitimários. Revista Jurídica Luso-Brasileira, Lisboa, ano 3, n. 4, p. 1337-1378, jul./ago. 2017.

VALLET DE GOYTISOLO, Juan. Apuntes de derecho sucesorio III: distinción de la colación con respecto a la computación, la imputación ex se y la reducción por inoficiosidad en los principales ordenamientos del occidente europeo. Anuario de Derecho Civil, Madrid, fasc. 2, p. 269-460, 1955.

VASCONCELlOS, Manoel da Cunha Lopes e (Conselheiro Vasconcellos) et alii. Digesto ou Pandectas do Imperador Justiniano. São Paulo: YK, 2017, v. 1.

. Digesto ou Pandectas do Imperador Justiniano. São Paulo: YK, 2018, v. 3.

VASCONCELOS, Pedro Pais de. Contratos atípicos. 2. ed. Coimbra: Almedina, 2009.

VAZ SERRA, Adriano Paes da Silva. União de contratos. Contratos mistos. Separata do Boletim do Ministério da Justiça, n. 91, Lisboa, 1960.

VELOSO, Zeno. Comentários ao Código Civil: da sucessão testamentária; do inventário e da partilha. São Paulo: Saraiva, 2003, v. 21.

VERÇOSA, Haroldo Malheiros Duclerc. Direito comercial: os contratos comerciais em espécie. São Paulo: Revista dos Tribunais, 2013, v. 5.

VICENTE, Dario Moura. A autonomia privada e os seus diferentes significados à luz do direito comparado. Revista de Direito Civil Contemporâneo, São Paulo, v. 8, ano 3, p. 275-302, jul./set. 2016.

VICTORIA, Diego Franco. Interpretación de los contratos: desde Roma hasta los inicios de la codificación: verbas contra voluntas. Revista de derecho privado, Colombia, n. 11, p. 127-153, 2006. 
VILLELA, João Baptista. Contrato de doação: pouca luz e muita sombra. In: PEREIRA JUNIOR, Antonio Jorge; JABUR, Gilberto Haddad (coord.). Direito dos contratos. São Paulo: Quartier Latin, 2006, p. 249-283.

VILLEY, Michel. Le droit romain. Paris: PUF, 2012.

. Essor et décadence du volontarisme juridique. Archives de Philosophie du Droit, Paris, t. 3, p. 87-98, 1957.

VIRGILIO. Eneida. In: MENDES, Manuel Odorico. Virgilio Brazileiro. Paris: W. Remquet e Cia., 1858.

ZANETTI, Ana Carolina Devito Dearo. Contrato de distribuição: o inadimplemento recíproco. São Paulo: Atlas, 2015.

ZANETTI, Cristiano de Sousa. A conservação dos contratos nulos por defeito de forma. São Paulo: Quartier Latin, 2013.

ZIMMERMANN, Reinhard. The law of obligations: roman foundations of the civilian tradition. Oxford: Oxford University Press, 1996.

. The new german law of obligations: historical and comparative perspectives. Oxford: Oxford University Press, 2005.

; WHITTAKER, Simon (ed.). Good faith in european contract law. Cambrigde: Cambridge University Press, 2000.

ZWEIGERT, Konrad; KÖTZ, Hein. Introducción al derecho comparado. Tradução Arturo Aparicio Vázquez. San Rafael: Oxford University Press, 2002.

WAISBERG, Ivo. Franquia. In: CARVALHOSA, Modesto (Coord.). Tratado de direito empresarial: contratos mercantis. São Paulo: Revista dos Tribunais, 2018, v. 4, p. $207-$ 224.

. Arrendamento mercantil. In: CARVALHOSA, Modesto (Coord.). Tratado de direito empresarial: contratos mercantis. São Paulo: Revista dos Tribunais, 2018, v. 4, p. $195-208$.

WEBER, Florence. Transactions marchandes, échanges rituels, relations personnelles: une ethnographie après le Grand Partage, Genèses, v. 41, p. 85-107, dez. 2000. 
WICKER, Guillaume; BOUCARD, Hélène. Les sanctions relatives à la formation du contrat. La Semaine Juridique, Lexisnexis, Suplemento ao n. 21, 25 mai. 2015.

WICKER, Guillaume. Force obligatoire et contenu du contrat. In: RÉMY-CORLAY, Pauline; FENOUILLET, Dominique. Les concepts contractuels français à l'heure des Principes du droit européen des contrats. Paris: Dalloz, 2003, p. 151-174.

WINDSCHEID, Bernhard. Diritto delle pandette. Tradução Carlo Fadda e Paolo Emilio Bensa. Torino: UTET, 1925, t. 1.

. Diritto delle pandette. Tradução Carlo Fadda e Paolo Emilio Bensa. Torino: UTET, 1904, v. 2, t. 1. 